\title{
QUALIDADE DE BULBOS DE CEBOLA EM FUNÇÃO DE DIFERENTES TRATAMENTOS PRÉ-COLHEITA
}

\author{
MARCOS DAVID FERREIRA \\ Engenheiro Agrônomo
}

Orientador: Prof. Dr. Keigo Minami

\begin{abstract}
Tese apresentada à Escola Superior de Agricultura "Luiz de Queiroz", Universidade de São Paulo, para obtenção do título de Doutor em Agronomia, Área de Concentração: Fitotecnia.
\end{abstract}

PIRACICABA

Estado de São Paulo - Brasil

Setembro -1999 
Dados Internacionais de Catalogação na Publicação (CIP) DIVISÃO DE BIBLIOTECA E DOCUMENTAÇÃO - Campus "Luiz de Queiroz"/USP

Ferreira, Marcos David

Qualidade de bulbos de cebola em função de diferentes tratamentos précolheita / Marcos David Ferreira. - - Piracicaba, 1999.

$90 \mathrm{p}$.

Tese (doutorado) - Escola Superior de Agricultura Luiz de Queiroz, 1999.

Bibliografia.

1. Cebola 2. Coloração 3. Hortaliça de bulbo 4. Maturação 5.

Micronutriente 6. Nutrição vegetal 7. Pré-colheita 8. Propriedade físico-química I. Titulo

CDD 635.25

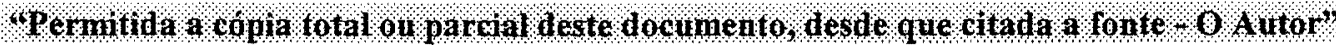




\section{AGRADECIMENTOS}

Manifesto meus sinceros agradecimentos às seguintes pessoas e instituições:

À SVS do Brasil Sementes Ltda, pela oportunidade e apoio na realização do curso de pós-graduação. Especial gratidão ao Sr. Martinho Alencar e Dr. Paulo César Tavares de Melo pela direta colaboração e apoio a este trabalho.

Aos funcionários da Estação Experimental de hortaliças da SVS do Brasil Sementes Ltda, em especial aos funcionários de campo, ao Sr. Rui Ribeiro e Srta. Sandra Carvalho.

Ao laboratório central do Departamento de Planejamento Alimentar e Nutrição da Faculdade de Engenharia de Alimentos, Universidade Estadual de Campinas, UNICAMP, em especial ao Prof. Dr. Carlos R.F. Grosso e ao Químico Francisco Carraro, pelas excepcionais condições fornecidas para realização das análises laboratoriais.

Ao Prof. Dr. Steven A. Sargent, do Horticulture Sciences Department, University of Florida; ao Prof. Dr. Francisco de Assis A. Mourão, da ESALQ-USP; ao Prof. Dr. José Fernando Durigan, da UNESP-Jaboticabal e ao Dr. Paulo Espíndola Trani, IACCampinas, pela amizade e sugestões a esse trabalho.

Aos professores, Dr. Cyro Paulino da Costa e Dr. João Tessarioli Filho, do Departamento de Horticultura, da ESALQ, pelas sugestões e correções deste trabalho.

Ao Prof. Dr. Keigo Minami, pela valiosa orientação, ensinamentos, filosofia de trabalho e amizade.

Aos estudantes Fernando Fernandes de Andrade, Karina Palareti Cassaro, Fernando Enrique Ninamango Cárdenas, Sergio Minoru Hanai, Thiago Sattin Vilas Boas e Gilberto Luís Landgraf pela colaboração a este trabalho.

Aos meus pais, Drauzio e Cacilda, e a minha esposa Ana Cristina, dedico este trabalho. 


\section{SUMÁRIO}

Página

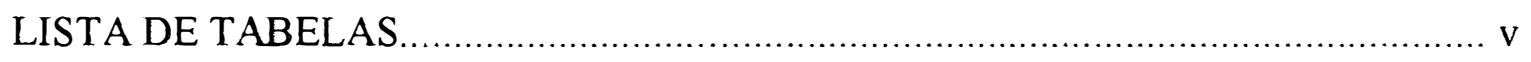

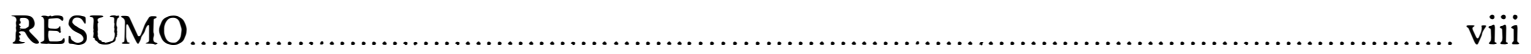

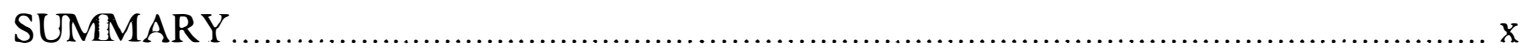

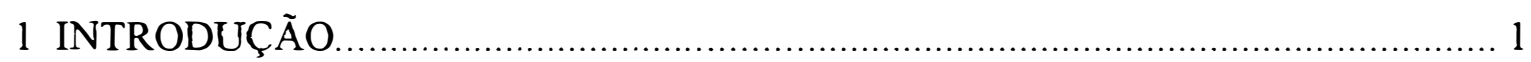

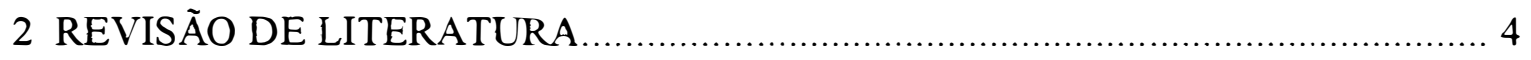

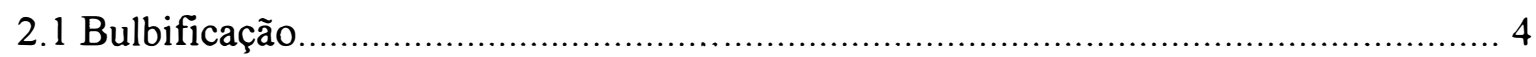

2.1.1 Processo de bulbificação....................................................................... 5

2.1.2 Fatores que afetam a bulbificação............................................... 7

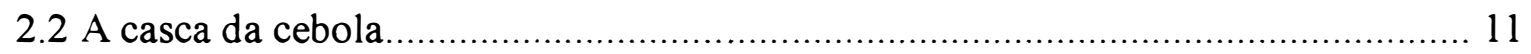

2.3 Genética da coloração dos bulbos e da espessura da casca.............................. 13

2.4 Manejo e fatores ambientais que influenciam a coloração da casca...................... 15

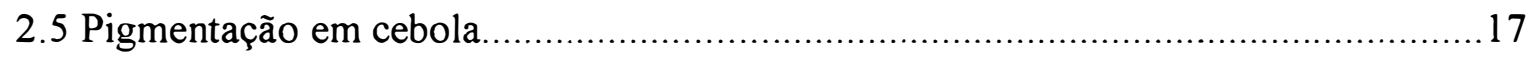

2.5.1 Fatores que influenciam a pigmentação da cebola............................ 21

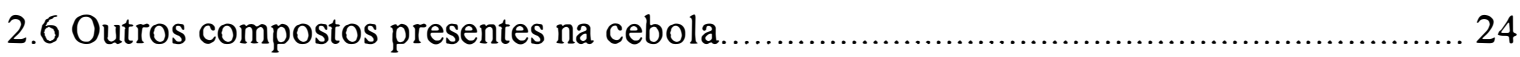

2.7 Efeito da nutrição no desenvolvimento da planta, qualidade do bulbo

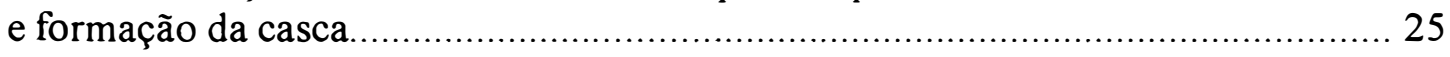

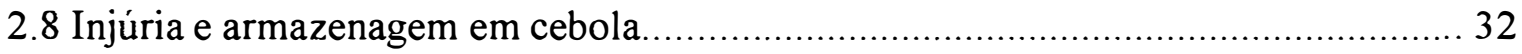




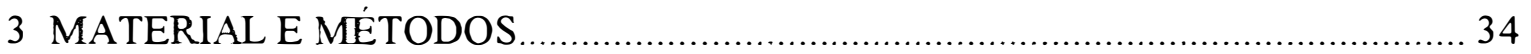

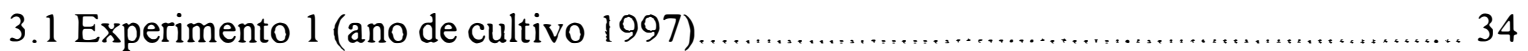

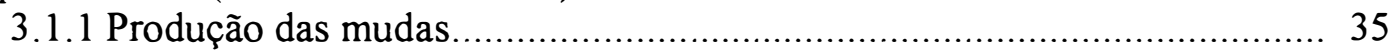

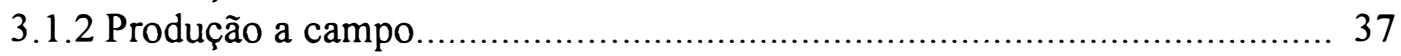

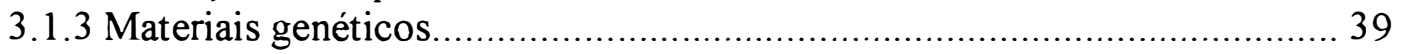

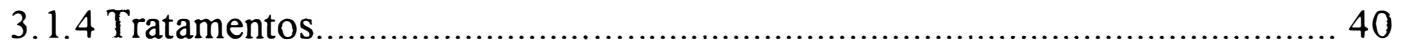

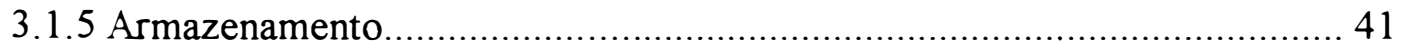

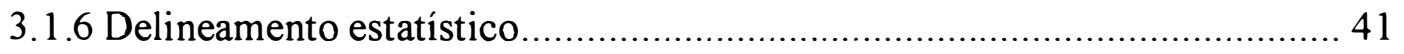

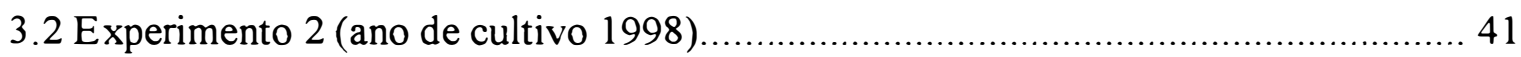

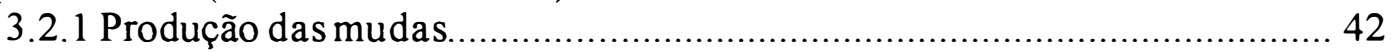

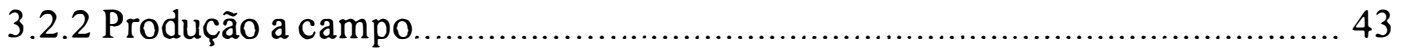

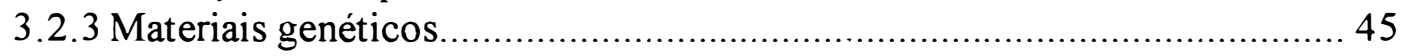

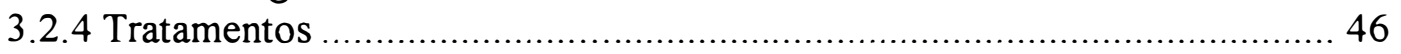

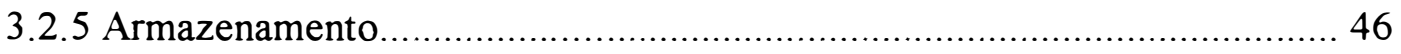

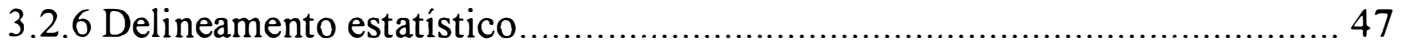

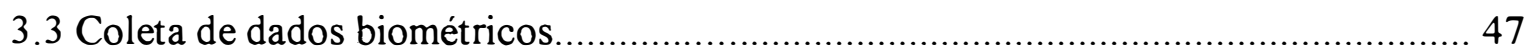

3.3.1 Perda de peso

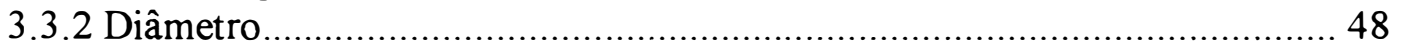

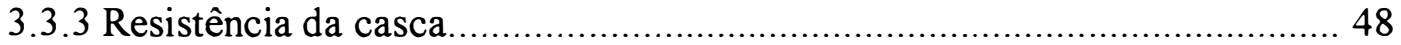

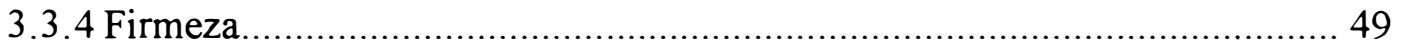

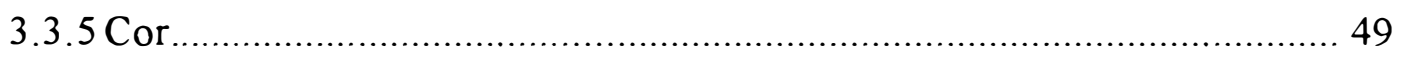

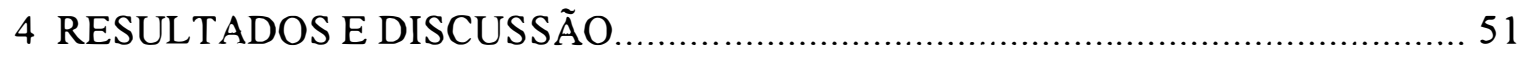

4.1 Resultados Experimento 1 (ano de cultivo 1997) …........................................... 51

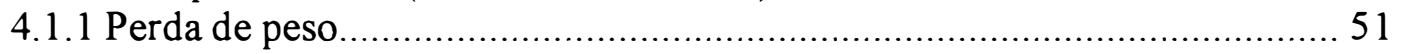

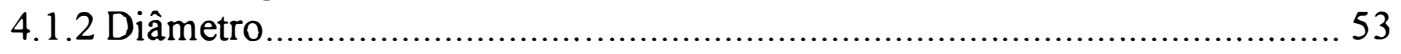

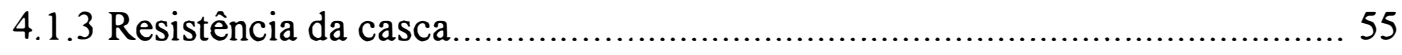

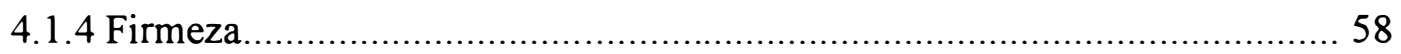

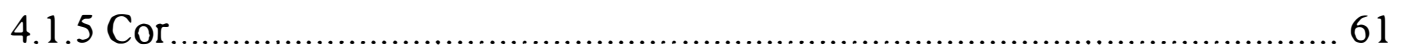

4.2 Resultados Experimento 2 (ano de cultivo 1998) ............................................... 71

4.2.1 Perda de peso

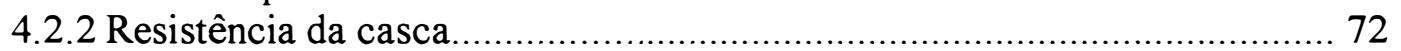

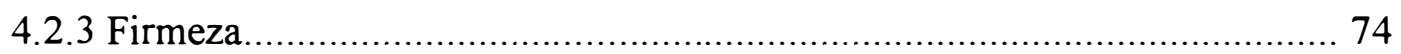

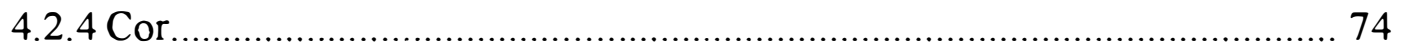

5 CONCLUSÕES

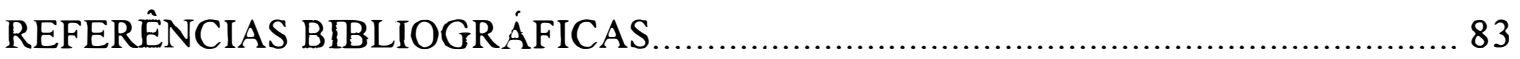




\section{LISTA DE TABELAS}

1 Médias mensais de temperatura (máxima, mínima e média) e totais de

Página chuva, medidas no posto metereológico da Estação Experimental SVS, durante o período de cultivo do Experimento 1 (1997).

2 Análise química do solo (0-20 $\mathrm{cm}$ de profundidade) anterior ao plantio, do local do Experimento 1 (1997), na Estação Experimental de Hortaliças SVS

3 Médias mensais de temperatura (máxima, mínima e média) e totais de chuva, medidas no posto metereológico da Estação Experimental SVS, durante o período de cultivo do Experimento 2 (1998).

4 Análise química do solo (0-20 $\mathrm{cm}$ de profundidade) anterior ao plantio do local do Experimento 2 (1998), Estação Experimental de Hortaliças SVS

5 Primeira e segunda avaliações realizadas aos 25 e 45 dias após a colheita para perda em peso (\%), em 6 cultivares de cebola, submetidos a tratamentos pré-colheita no Experimento 1

6 Resultados de 2 avaliações realizadas aos 7 e 45 dias respectivamente para diâmetro do bulbo $(\mathrm{mm})$ em 6 cultivares de cebola submetidos a tratamentos pré-colheita no Experimento 1

7 Resultados da primeira e segunda avaliações realizadas aos 40 e 70 dias após colheita para espessura de casca (Força expressa em Newtons) em 6 cultivares de cebola submetidos a tratamentos pré-colheita no Experimento 1

8 Resultados da primeira e segunda avaliações realizadas aos 10 e 25 dias após a colheita, para firmeza dos bulbos (Força expressa em Newtons) em 6 cultivares de cebola submetidos a tratamentos pré-colheita no Experimento 1 
9 Resultados da terceira e quarta avaliações realizadas aos 60 e 70 dias após a colheita para firmeza dos bulbos (Força expressa em Newtons) realizada em 6 cultivares de cebola submetidos a tratamentos pré-colheita no Experimento 1

10 Resultados da primeira avaliação para o parâmetro L e o ângulo hue dos bulbos realizada aos 7 dias após a colheita em 6 cultivares de cebola submetidos a tratamentos pré-colheita no Experimento $1 . .$.

11 Resultados da primeira avaliação para coloração, parâmetro Chroma, realizada aos 7 dias após a colheita em 6 cultivares de cebola submetidos a tratamentos pré-colheita no Experimento 1.

12 Resultados da segunda avaliação para o parâmetro L e o ângulo Hue dos bulbos realizada aos 40 dias após a colheita em 6 cultivares de cebola submetidos a tratamentos pré-colheita no Experimento 1

13 Resultados da segunda avaliação para coloração, parâmetro Chroma, realizada aos 30 dias após a colheita em 6 cultivares de cebola submetidos a tratamentos pré-colheita no Experimento 1 .

14 Resultados da terceira avaliação para coloração, parâmetro L e ângulo Hue realizada aos 60 dias após a colheita em 6 cultivares de cebola submetidos a tratamentos pré-colheita no Experimento 1

15 Resultados da terceira avaliação para coloração, parâmetro Chroma, realizada aos 60 dias após a colheita em 6 cultivares de cebola submetidos a tratamentos pré-colheita no Experimento 1 ....

16 Resultados da avaliação para perda de peso de bulbos (\%) baseada na diferença entre a pesagem de 10 dias e 40 dias após a colheita em 3 cultivares de cebola submetidos a tratamentos pré-colheita no Experimento 2 (1998).

17 Resultados da avaliação para espessura da casca (força em Newtons) realizada aos 30 dias após a colheita em 3 cultivares de cebola submetidos a tratamentos pré-colheita no Experimento 2

18 Resultados da primeira, segunda e terceira avaliação, 30, 75 e 90 dias, após a colheita para firmeza dos bulbos (força expressa em Newtons) em 6 cultivares de cebola submetidos a tratamentos pré-colheita no Experimento 2 
19 Resultados da primeira avaliação para os parâmetros L, ângulo hue e chroma realizada aos 30 dias após a colheita em 3 cultivares de cebola submetidos a tratamentos pré-colheita no Experimento 2 .

20 Resultados da segunda avaliação para os parâmetros L, ângulo hue e chroma realizada aos 75 dias após a colheita em 3 cultivares de cebola submetidos a tratamentos pré-colheita no Experimento 2 .

21 Resultados da terceira avaliação para os parâmetros L, ângulo hue e chroma realizada aos 90 dias após a colheita em 3 cultivares de cebola submetidos a tratamentos pré-colheita no Experimento 2 . . 


\title{
QUALIDADE DE BULBOS DE CEBOLA EM FUNÇÃO DE DIFERENTES TRATAMENTOS PRÉ-COLHEITA
}

\author{
Autor: MARCOS DAVID FERREIRA \\ Orientador: Prof. KEIGO MINAMI
}

\section{RESUMO}

Com o objetivo de se avaliar o efeito de tratamentos pré-colheita na qualidade de bulbos de cebola, através dos parâmetros perda de peso, espessura e coloração da casca, diâmetro e firmeza do bulbo, foram desenvolvidos experimentos na Estação Experimental de Hortaliças da SVS do Brasil Sementes Ltda, Paulínia, Estado de São Paulo, em 1997 e 1998. Em 1997, foram utilizados quatro tratamentos: testemunha; oxicloreto de cobre, 250g/100L de água; ácido bórico, 250g/100L de água; e a combinação dos dois últimos e seis cultivares: Serrana, Régia, Crioula e três híbridos da SVS, HT, HS-1 e HS-2. Em 1998, foram também utilizados quatro tratamentos, sendo o tratamento proveniente da combinação de oxicloreto de cobre com o ácido bórico substituído pela aplicação com cloreto de cálcio, 100g/100L de água. Foram utilizadas somente três cultivares, já cultivadas no ano de 1997, Serrana, Crioula e o híbrido HS-1. Nos dois experimentos os tratamentos foram aplicados durante a bulbificação. Os bulbos foram armazenados à temperatura ambiente $\left(25^{\circ} \mathrm{C}\right)$ e analizados periodicamente para os parâmetros citados. Os resultados permitem observar que a aplicação pré-colheita do oxicloreto de cobre, nas quatro últimas semanas do ciclo, aumentou significativamente a resistência da casca dos 
bulbos, reduziu a perda de peso e incrementou a coloração dos mesmos, para todas as cultivares, em 1997. Cultivares com casca mais escura permitem melhor resposta aos tratamentos pré-colheita para a coloração, do que as de casca mais clara. A firmeza, não foi influênciada pelos tratamentos pré-colheita, nas duas safras estudadas. Em 1998, bulbos tratados com oxicloreto de cobre ou cloreto de cálcio demonstraram incremento visual na coloração e na firmeza, que não foi detectado estatísticamente. 


\title{
ONION BULB QUALITY DUE TO \\ PRE-HARVEST TREATMENTS
}

\author{
Author: MARCOS DAVID FERREIRA \\ Adviser: Prof. KEIGO MINAMI
}

\section{SUMMARY}

Pre-harvest treatments were evaluated to enhance onion bulb quality in different onion cultivars adapted to tropical conditions. The parameters used for that were weight loss, skin color and thickness, bulb diameter and firmness. Trials were carried out at the SVS do Brasil Sementes, Experimental Station, Paulínia, São Paulo State, in the years 1997 and 1998. Four treatments were used in 1997: control, copper oxicloride $(250 \mathrm{~g} / 100 \mathrm{~L})$; boric acid $(250 \mathrm{~g} / 100 \mathrm{~L})$, and a combination of the two treatments $(250 \mathrm{~g} / 100 \mathrm{~L}$ of each one). Treatments were applied at bulbing stage, in the weeks prior to harvest, in 6 cultivars: Serrana, Régia, Crioula, and the hybrids HT, HS-1 and HS-2. In 1998, four treatments were also used, with the treatment (copper oxicloride, $250 \mathrm{~g} / 100 \mathrm{~L}+$ boric acid, 250g/100L) was replaced by Calcium chloride, $100 \mathrm{~g} / 100 \mathrm{~L}$. Cultivars Serrana, Crioula and the hybrid HS-1 were planted in the second trial. Bulbs were stored at room temperature prior to analyses. The results showed that copper 
oxicloride $(250 \mathrm{~g} / 100 \mathrm{~L})$ induced an increase in skin thickness, decrease in weight loss and enhance color enhance in cultivars, in year of 1997. Dark skin cultivars showed better response to pre-harvest treatments than light skin cultivars. Firmness was not affected due to pre-harvest treatments. For the year 1998, bulbs showed a visual increase in color and firmness due to pre-harvest treatments, but these differences were not significant different. 


\section{INTRODUÇÃO}

O Brasil produziu em 1998, 874.716 toneladas de cebola, classificando-se como décimo produtor mundial dessa cultura (FNP Consultoria e Comércio, 1999). Com a criação do Mercosul - Mercado Comum do Sul, o Brasil passou a importar da Argentina cebola com boa qualidade, uniforme, sabor pungente e casca marrom-escura. As importações deste bulbo da Argentina pelo Brasil, em 1994, anterior a criação do MERCOSUL, eram de 137.970 t. Em 1995, passaram a 307.923 t; em 1996, foram 409.523 t e em 1997, 262.209 t (FNP Consultoria e Comércio, 1999). Observa-se que em alguns anos houve um aumento de até 3 vezes o volume importado anteriormente à criação do Mercosul.

Este aumento é devido à reação do consumidor brasileiro, que passou a preferir a cebola argentina em detrimento da nacional. Para se tornarem competitivos neste mercado, os produtores brasileiros buscam por uma cebola com casca mais escura e cujo cultivo seja adaptado às condições tropicais.

$\mathrm{Na}$ Argentina, $80 \%$ da cebola cultivada é da cultivar Sintética Valenciana 14 , com baixa cerosidade, ciclo longo e bulbos com casca marrom-escura (Acosta et al., 1993). Além desta maior aceitabilidade, os campos produtores da Argentina mostram uma 
eficiência 50\% superior à apresentada pelas lavouras brasileiras (Boeing, 1995). No Brasil, a média nacional de produtividade em cebola está em torno de 12 t/ha, mas algumas regiões no Estado de São Paulo possuem médias de produtividade superiores (Boeing, 1995). Os principais Estados produtores, em 1998, foram: Santa Catarina (268.000 t), São Paulo (245.290 t), Rio Grande do Sul (165.993 t), Pernambuco (63.730 t), Bahia (56.582 t), Paraná (56.400 t) e Minas Gerais (19.028 t) (FNP Consultoria e Comércio, 1999). O Estado de São Paulo apresentou uma redução da produção de cerca de $20 \%$ em relação a 1994, ano em que se criou o Mercosul (FNP Consultoria e Comércio, 1999).

O custo médio para produzir, no Brasil, tem variado de US\$ 0,10 a 0,15 (dez a quinze centavos de dólar) por quilo (FNP Consultoria e Comércio, 1999), enquanto que o preço médio recebido pelos produtores, nos últimos 5 anos, tem sido de US $\$ 0,26$ (vinte e seis centavos de dólar) por quilo produzido (FNP Consultoria e Comércio, 1999). O menor custo refere-se às regiões com maior produtividade e sistema de cultivo por semeadura direta, como por exemplo, Monte Alto, no Estado de São Paulo (FNP Consultoria e Comércio, 1999). O maior custo refere-se ao sistema de produção pelo método do bulbinho e a produção por mudas possui custo intermediário, US\$ 0,13 (treze centavos de dólar) por quilo produzido. O custo médio para a produção da cebola argentina assemelha-se ao brasileiro, US\$ 0,14 (quatorze centavos de dólar) por quilo produzido (Boeing, 1995). 
Há diversos fatores que afetam a qualidade e a coloração dos bulbos, como: ponto de maturação, épocas de colheita (Tucker \& Drew, 1982), e efeitos da nutrição (Bender, 1993; Brewster \& Butler, 1989). Knott (1933), trabalhando com produtores de cebola no Estado de Nova York, Estados Unidos, relata a importância das aplicações de sulfato de cobre na coloração e qualidade dos bulbos de cebola. Comunicação pessoal de produtores e técnicos da extensão rural, principalmente das regiões de Piedade (SP) e de Ituporanga (SC), corroboram com essa hipótese. Outros micronutrientes também têm sido relacionados, com a qualidade dos bulbos, como o descrito por Calbo et al. (1986), que a deficiência em B ocasiona a má formação das cascas externas.

Grande parte dos estudos para melhoria da qualidade dos bulbos, coloração e espessura da casca de cebola tem sido realizados com cultivares de clima temperado, de ciclo longo, e sabidamente com cascas de coloração escura (Ellerbrock, 1997; Knott, 1933). A aplicação de micronutrientes nessas situações tem sido efetuada via solo visando uniformizar e incrementar a coloração e a espessura da casca.

O trabalho em pauta buscou avaliar o efeito da aplicação de tratamentos na précolheita, durante o processo de bulbificação, dos nutrientes, cálcio, cobre e boro, na formação e coloração da casca, assim como conservação dos bulbos de cebolas de diferentes cultivares adaptadas às condições tropicais. 


\section{REVISÃO DE LITERATURA}

O cultivo da cebola (Allium cepa L.), da semente a floração, apresenta ciclo bianual: em um ano ocorre a formação dos bulbos e em outro, o florescimento (Werner \& Seben, 1983). Na formação dos bulbos, (bulbificação) várias modificações na planta estão envolvidas (Sobeih, 1988) e, dentre elas a formação da casca, influenciada por vários fatores, e influindo na qualidade do bulbo (Currah \& Proctor, 1990). Entre os fatores tem-se os ligados ao ambiente, podendo-se relacionar a adubação (Knott, 1993; Bender, 1993) e a temperatura (Cardoso et al., 1995) e os ligados à genética do material (Doruchowski, 1986a) e também a pigmentação da casca (Fossen et al., 1996; Patil \& Pike, 1995)

\subsection{Bulbificação}

A cebola é classificada fisiologicamente como uma planta que exige dias longos, para sua bulbificação. Independentemente da cultivar e das condições climáticas e de manejo, esta cultura sempre necessita de um determinado comprimento do dia para que sua bulbificação se inicie (Currah \& Proctor, 1990). Outros fatores como a temperatura, a nutrição e o espaçamento influenciam o processo de bulbificação. Fatores internos, 
como a idade e o tamanho da planta afetam a resposta aos estímulos externos (Currah \& Proctor, 1990).

O bulbo formado é do tipo tunicado simples. Comparativamente, o alho (Allium sativum) é classificado como bulbo composto (Da Glória, 1995). No bulbo tunicado, as folhas modificadas, (catáfilos, túnicas ou escamas) estão dispostas de modo concêntrico, e estas são ricas em reservas, com exceção das mais externas que são membranáceas. Os catáfilos são folhas modificadas, geralmente escamiformes com consistência variável, freqüentemente sem clorofila e podem ser encontrados em gemas, rizomas e bulbos (Ferri et al., 1981).

Acosta et al. (1993) fazem uma detalhada descrição de um bulbo de cebola, que apresenta da parte externa para a interna os seguintes componentes: (a) 6-7 catáfilos, membranosos e muito delgados: bainhas das primeiras folhas das folhagens, que com o desenvolvimento do bulbo se destacam; (b) 4-5 catáfilos camosos: bainhas engrossadas das folhas que formam a folhagem; (c) 6-8 catáfilos camosos: formados depois do começo do processo de bulbificação, no qual não ocorre o aparecimento de folhagem; e (d) 3-4 folhas não desenvolvidas, no centro do talo, que brotarão no próximo ciclo.

\subsubsection{Processo de bulbificação}

O mecanismo pelo qual o meio ambiente influencia a bulbificação não está totalmente esclarecido (Sobeih, 1988). Ocorrem mudanças na assimilação, translocação e acúmulo de nutrientes e carboidratos. Há evidências de acúmulo de carboidratos 
durante o início da bulbificação, em resposta a longos fotoperíodos. A presença de altas taxas de hormônios pode estar relacionada com este acúmulo de carboidratos (Sobeih, 1988).

O ciclo fisiológico da cebola, da semente à floração, é dividido em duas etapas: a primeira de formação do bulbo e a segunda de floração e formação das sementes (Werner \& Seben, 1983). Na fase de maturação do primeiro ciclo, quando os bulbos atingiram seu pleno desenvolvimento, há uma queda da planta, conhecido como "estalo". A concentração dos hormônios responsáveis pelo crescimento diminui nas folhas e nos bulbos e, ao mesmo tempo, a concentração de ácido abscísico aumenta, causando a dormência do bulbo.

Vários outros fatores internos à planta afetam o processo de bulbificação, tais como o tamanho da planta, a idade e a competição entre plantas.

Há indicações de que as folhas são os receptores do estímulo da variação do fotoperíodo para bulbificação. A desfoliação pode atrasar a maturidade da cultura e tem alto impacto na produção total, em especial quando ocorre próximo da maturidade das plantas (Bartolo et al., 1994). A remoção do ápice da planta também favorece a bulbificação (Terabun, 1970). Em relação a influência das raizes, a redução dessas, é em geral, um resultado do processo de bulbificação e não a causa (Rabinovick \& Brewster, 1990). 


\subsubsection{Fatores que afetam a bulbificação}

\section{Fotoperiodo}

As cultivares variam bastante quanto à resposta ao comprimento do dia para a indução da bulbificação (Currah \& Proctor, 1990; Rabinovick \& Brewster, 1990). A taxa de desenvolvimento do bulbo aumenta a partir do ponto de maturidade. Mondal et al. (1986), pesquisando a influência da época de plantio de cultivares tardios e precoces, observaram diferentes comportamentos quando estes foram expostos a diferentes fotoperiodos. Cultivares tardios necessitam de maior comprimento do dia para iniciarem a bulbificação, diferentemente das cultivares precoces.

Rabinovick \& Brewster (1990) relatam que a idade da planta também influencia na resposta ao fotoperíodo. Plantas mais velhas são mais sensíveis às mudanças no fotoperíodo do que plantas mais novas com tamanho similar. Sobeih \& Wright (1986) confirmam que a idade das plantas é fundamental para a resposta ao fotoperíodo. Plantas jovens respondem ao fotoperíodo produzindo mais folhas e somente quando possuírem uma determinada idade ocorrerá o estímulo à bulbificação. Iwama \& Hamashima (1953) relatam que esse estímulo pode ocorrer com 4 a 6 folhas. O atraso na bulbificação, observado em plantas jovens, quando comparado a plantas adultas, pode ser devido à insuficiente área foliar, e à não-resposta de meristemas jovens ao estímulo da bulbificação (Bernier et al., 1981). Por sua vez, Jones \& Mann (1963) afirmam que mudas de cebola 
com duas folhas podem bulbificar, com a combinação correta do fotoperíodo e da temperatura.

Em condições experimentais, a taxa de bulbificação cresce mais rapidamente à medida que a intensidade de luz aumenta. Plantas desenvolvidas em condições de fotoperíodos curtos e com baixa irradiação aumentam a taxa de bulbificação mais rapidamente, quando transferidas para fotoperíodos longos e com alta irradiação do que plantas crescidas em fotoperíodos curtos e com alta irradiação e transferidas para fotoperíodos longos e com baixa irradiação (Wright \& Sobeih, 1986). As cultivares respondem diferentemente ao fotoperiodo (Mondal et al., 1986). Vários autores (Currah \& Proctor, 1990 ; Rabinovick \& Brewster, 1990; Wright \& Sobeih, 1986) afirmam que a intensidade da luz também afeta a bulbificação. Isto é fundamentado por Kato (1965) ao mostrar que a bulbificação em cebola pode ser prevenida por baixa irradiação de luz e por Rabinovick \& Brewster (1990) ao descreverem que o sombreamento de plantas afeta a bulbificação. O comprimento de onda da luz incidente também é modificado pelas folhas verdes (Mondal et al., 1986).

\section{Temperatura}

A temperatura possui uma grande influência na bulbificação, acelerando-a (Rabinovick \& Brewster, 1990). Há uma interação entre o fotoperíodo e a temperatura, ou seja, quanto maior a temperatura, menor o fotoperíodo mínimo para indução à 
bulbificação (Steer, 1980). Portanto, uma rápida bulbificação pode ocorrer em temperaturas altas (Currah \& Proctor, 1990).

Temperaturas noturnas altas aceleram o processo de bulbificação (Steer, 1980). Altas temperaturas, quando aliadas a fatores como o excesso de irrigação podem afetar a bulbificação, favorecendo a formação de "bulbos duplos" ("bulb spliting"). O formato do bulbo também é altamente afetado pela temperatura do solo (Steer, 1980). Brewster et al. (1987) descrevem que temperaturas baixas do solo durante o crescimento da planta, favorecem o aparecimento de "thick-necks", também conhecidos como "pescoço-grosso" ou "charutos", ou seja, plantas com excesso de desenvolvimento.

\section{Nitrogênio e suprimento de água}

$\mathrm{O}$ nitrogênio e a irrigação afetam a bulbificação. Níveis excessivos de $\mathrm{N}$ causam atraso e reduzem a bulbificação (Della Vechia, 1974). Por sua vez, alguns trabalhos demonstram que niveis menores de $\mathrm{N}$ favorecem a bulbificação naquelas cultivares desenvolvidas em fotoperíodos próximos ao adequado (Fontes, 1980). O início da maturidade pode ser atrasado pelo baixo teor de nitrogenados, existindo um nível crítico em que a formação de bulbos é afetada pelos baixos teores (Rabinovick \& Brewster, 1990). Brewster et al. (1987) demonstraram uma correlação positiva entre a presença de "charutos", plantas com excesso de desenvolvimento e o aumento na adubação nitrogenada. 
A irrigação em excesso, além de favorecer a formação de "bulbos duplos", também prolonga o crescimento das folhas e atrasa o processo de maturação. Atrasos na maturidade dos bulbos, causados por excesso de irrigação, na ordem de 5 e 19 dias, foram relatados por Riekels (1977).

\section{Espaçamento}

A bulbificação precoce pode ocorrer em espaçamentos menores. A competição entre plantas afeta a competição por luz e pode influir no processo de bulbificação. Em plantas conduzidas sob condições ideais, a bulbificação é acelerada com alta densidade de plantas (Rabinovick \& Brewster, 1990). Mondal et al. (1986) observaram o comportamento de diferentes cultivares de cebola, em diferentes densidades, 25, 100 e 400 plantas $/ \mathrm{m}^{2}$, em duas épocas de semeadura. Observou-se, na maior densidade e sob fotoperíodo crescente, uma precocidade de 46 dias no ponto de colheita. Por sua vez, em diferentes épocas de semeadura, plantas expostas a alta densidade apresentaram folhas estioladas. As cultivares de cebola responderam diferentemente à bulbificação, dependendo da época da semeadura. Aparentemente, cultivares de dias longos são mais influenciadas pela densidade de plantio e época da semeadura do que as cultivares de dias curtos. Uma das razões apontadas para isto relaciona-se à competição por luz. 


\subsection{A Casca da cebola}

Segundo Currah \& Proctor (1990), o processo de formação da casca não está totalmente esclarecido. A planta para de emitir folhas e inicia a formação de escamas grossas, que posteriormente formarão a casca. Durante o estádio de formação do bulbo, a maior parte da massa da planta se transfere das folhas para os bulbos, contribuindo para a formação das escamas. As escamas externas são formadas das folhas secas da base da planta. Lancaster \& Gandar (1986) relatam que bulbos maduros da cultivar Spartan Sleeper, plantado na Nova Zelândia, possuem de 9 a 12 escamas, formadas após o início do processo de bulbificação, ou seja quando a planta estava com cerca de oito folhas.

Antes do início da bulbificação ocorre um momento de rápida formação foliar e aparentemente, as folhas formadas por último serão as futuras escamas dos bulbos. Considerável crescimento ocorre nos elementos vasculares da parte externa dessas folhas, proporcionando ao bulbo de cebola expansão para o seu tamanho final, enquanto permanece recoberto pelas folhas da base (Currah \& Proctor, 1990). Mondal et al. (1986) relatam que a taxa de crescimento das folhas declina durante o desenvolvimento dos bulbos até a formação das escamas. Quando os catáfilos (escamas) estão sendo formados, as folhas novas cessam de crescer dentro do pseudocaule e quando o lumem das folhas já existentes se forma, o pseudocaule torna-se oco e perde a firmeza. A perda da firmeza do pseudocaule, característica de maturidade, é conseqüência da transição para a formação das escamas. Este estádio caracteriza-se pelo tombamento da planta e tem sido denominado de "estalo". 
As características geneticamente transmissiveis, como a porcentagem de sólidos solúveis, a pungência, a cor da casca, o número de escamas e a dormência do bulbo influenciam a qualidade e a capacidade de armazenamento do mesmo. A casca da cebola deve se manter aderida ao bulbo, funcionando como uma barreira contra injúrias, doenças e perda de água (Apeland, 1971).

Quanto maior o número de escamas maior será a probabilidade de se ter melhor armazenamento e qualidade desses bulbos. A perda da casca dobra a taxa de perda de peso durante a armazenagem, assim como promove a brotação (Apeland, 1971). Cebolas com alta dormência, geralmente, mantém a casca por um maior periodo e, portanto se mantém com qualidade superior.

A coloração da casca per se não influencia o periodo de armazenamento e a qualidade do bulbo, mas atua como atrativo visual (Bleasdale et al., 1970). Há variação na espessura da casca do bulbo de cebola. Em geral, a casca é mais grossa no topo do bulbo (local da inserção das folhas) do que na base, com as rachaduras acontecendo nas áreas mais finas. Espessura e firmeza de casca são caracteristicas diretamente relacionadas (Tanaka et al., 1995).

A densidade de plantio e a época de semeadura afetam o início da época de formação das escamas da cebola (Mondal et al., 1986). A área foliar de uma cultura tem maior influência na formação da casca do que a idade da planta. Fatores ambientais externos, na época da bulbificação, são mais importantes do que os fatores externos prévios a esta época. À medida que o estímulo para bulbificação aumenta (dias longos e aumento da temperatura), as diferenças para o início da formação dos catáfilos, assim 
como o ponto de maturidade entre as diferentes cultivares ficam menores (Mondal et al., 1986).

\subsection{Genética da coloração dos bulbos e da espessura da casca}

El-Shafie \& Davis (1967) relatam que a coloração dos bulbos de cebola varia do branco, a diversas tonalidades de amarelo e vermelho. A coloração do bulbo é devido a três pares de genes que interagem entre si ( $\mathrm{Ii}, \mathrm{Cc}, \mathrm{Rr})$. O gene $\mathrm{I}$, chamado de inibidor, na forma dominante, condiciona a coloração branca, independentemente dos outros 2 pares de genes que só se manifestam quando esse gene inibidor se encontra no estado homozigoto recessivo (ii). Satisfeita essa condição, o gene $\mathrm{R}$ e o gene $\mathrm{C}$, ambos na forma dominante, condicionam a coloração roxa. Se o gene R se encontra na forma homozigota recessiva (ii) e o gene $\mathrm{C}$ na forma dominante tem-se a coloração amarela. Se o gene $\mathrm{C}$ encontrar-se no estado homozigoto recessivo (cc), tem-se bulbos brancos, independentemente do gene $\mathrm{R}$ se encontrar na forma dominante ou recessiva (El-Shafie \& Davis, 1967; Patil et al., 1971; Pike, 1986;). El-Shafie \& Davis (1967) também propuseram a adição de mais dois genes para a coloração dos bulbos, os genes L e G. O gene $\mathrm{L}$ produz coloração amarelo-clara e é complementar ao gene $\mathrm{R}$, determinando a coloração vermelho-clara. $\mathrm{O}$ gene $\mathrm{G}$, na condição homozigota ou heterozigota, produz coloração amarelo-escura, sem o adicional rosado.

A cor do bulbo tem sido associada não somente à classificação e comercialização, mas também a outros fatores, tais como resistência a doenças e peso do bulbo (El-Shafie 
\& Davis, 1967). Clarke et al. em 1944, conforme citação de El-Shafie \& Davis (1967), já indicavam que o alelo (I) pode estar direta ou indiretamente associado com bulbos pequenos.

Doruchowski (1986a) estudou a herdabilidade em cebola, para várias características, em uma população de 15 híbridos $F_{1}, 11$ progênies $F_{2}$ e 16 parentais componentes (8 linhagens macho-estéreis A e 8 linhagens C). Algumas das características estudadas possuiam alta herdabilidade, como por exemplo, o peso dos bulbos e o diâmetro. Menor herdabilidade foi demonstrada para o parâmetro firmeza. Os coeficientes de herdabilidade encontrados foram, para o peso variando de $51,3 \%$ a $71,9 \%$, para a altura do bulbo entre $30-80 \%$, para o diâmetro entre $50-70 \%$, para a espessura da casca entre $30-60 \%$, para a espessura do talo junto a inserção ao bulbo entre $30-50 \%$ e para a firmeza do bulbo entre $32-48 \%$. O altos valores de herdabilidade encontrados sugerem que a variabilidade em híbridos $F_{1}$ é determinada de $30 \%$ a $70 \%$ por fatores genéticos e de 30 a $50 \%$ por fatores ambientais. A espessura de casca mostrou baixo coeficiente de herdabilidade e alta variabilidade entre as linhagens. Observou-se também a grande influência do ambiente para essas características. Como a qualidade da casca das diferentes linhagens utilizadas, em relação à espessura é altamente variável, o autor sugeriu a necessidade de um maior número de linhagens para se obter híbridos $F_{1}$ com casca mais espessa.

A aderência da casca demonstrou, nesse estudo, uma dominância parcial dos materiais com casca mais aderente nos híbridos $F_{1}$. Linhagens caracterizadas por alta variabilidade para essa característica demonstraram nos híbridos $F_{1}$, alta variabilidade e 
alta influência às mudanças ambientais. Para a obtenção de híbridos com casca bem aderida, o autor sugeriu que os parentais possuam essa característica.

Quando se utilizou um parental com casca de coloração escura e uma linhagem com coloração clara, o híbrido $F_{1}$ apresentava coloração intermediária, mais clara que o seu parental de coloração mais escura. Observou-se maior variação das plantas de cebola para essa característica em diferentes condições ambientais.

Por sua vez, Knott (1933) relatou que a coloração da casca está relacionada com o ambiente e não com a herdabilidade; pois fatores ambientais podem afetar a espessura e coloração da casca. Doruchowski (1986b) relata que a boa aderência da casca esta relacionada com à coloração do bulbo. Quanto mais escura a coloração do bulbo, melhor

é a aderência da casca ao mesmo. O autor sugeriu que para melhorar a aderência da casca, devem ser utilizadas linhagens com coloração escura. A espessura e a aderência da casca são características que se diferenciam entre variedades e linhagens de cebola (Tanaka et al., 1995).

\subsection{Manejo e fatores ambientais que influenciam a coloração da casca}

Em geral, aumenta-se a produtividade quando os bulbos são deixados no campo até a completa secagem das ramas, devido a translocação de nutrientes das folhas para os bulbos. Esta situação pode levar a ocorrência de maior incidência de doenças durante armazenagem e também a uma maior perda da cascas externas (Currah \& Proctor, 1990). 
Fustos (1997) relata que colheita tardia reduz a qualidade e o número das camadas externas de cebola.

A maioria dos trabalhos recomenda que a colheita deve ser feita quando no mínimo 50\% das plantas estiverem tombadas (Celaro \& Gomes, 1987; Wright \& Grant, 1996). A colheita nesse estádio tem como objetivo se obter melhor coloração de casca. Sargent et al. (1991), trabalhando com diversos pontos de colheita do híbrido Granex 33 e da cultivar Texas Grano 1015, concluiram que quanto maior a porcentagem de plantas estaladas, melhor foi a qualidade dos bulbos durante o armazenamento.

Tucker \& Drew (1982) relataram que coloração da casca de cebola torna-se mais intensa, à medida que se atrasa a data da colheita. Wright \& Grant (1996) também observaram que a qualidade pós-colheita dos bulbos da cultivar Pukekohe Longkeeper, de casca marrom-escura, está relacionada com o ponto de colheita. Bulbos colhidos no estádio em que $10 \%$ das plantas estavam estaladas apresentaram maior retenção de casca (95\% dos bulbos apresentaram três ou mais escamas intactas). Esses bulbos apresentaram também alta incidência de podridão bacteriana $(61 \%)$. A coloração da casca não foi afetada pelo ponto de colheita, pelo tipo de cura (artificial ou a campo), ou por irrigações durante o processo de cura (Wright \& Grant, 1996). Por sua vez, Celaro \& Gomes (1987) relatam a importância da cura para se alcançar uma coloração mais intensa.

Cardoso et al. (1995) pesquisaram que fatores ambientais podem influenciar na coloração dos bulbos. Analisando um mesmo lote da cultivar Pira Ouro, que segrega para bulbos arroxeados, observaram que a proporção de bulbos fortemente arroxeados 
tende a ser maior em condições ou locais de temperatura mais elevada. Bulbos de cebola com melhor formato, coloração e firmeza da casca vieram de campos com solo arenoso e que se aquecem mais rapidamente (Safarikova, 1986). Tucker \& Drew (1982) relatam que o atraso na colheita proporcionou bulbos com coloração mais intensa, e que está coloração esta relacionada com as altas temperaturas no campo, anteriores à colheita. Bulbos com melhor coloração foram mais encontrados a $30{ }^{\circ} \mathrm{C}$, do que a $20{ }^{\circ} \mathrm{C}$. A melhor qualidade da casca foi obtida em bulbos colhidos mais cedo e condicionados a $30{ }^{\circ} \mathrm{C}$ e $60 \%$ UR.

Knott (1933) descreve que cebolas cultivadas em solos com alta presença de umidade, em especial na última fase do ciclo, demonstraram coloração mais acentuada do que aquelas cultivadas em solo seco. Observações a campo sugerem uma estreita relação entre umidade disponível no fim do ciclo e a coloração dos bulbos de cebola. Chung (1989) observa que a irrigação durante a fase final da bulbificação aumenta a perda por podridões durante o armazenamento, mas não afeta a formação da casca. Por sua vez, Wright \& Grant (1996) descrevem que bulbos sujeitos à irrigação, durante o processo de cura, perdem a casca mais rapidamente.

\subsection{Pigmentação da cebola}

A coloração de frutas e hortaliças resulta de pigmentos como a clorofila e os carotenóides nos cloroplastos e cromoplastos e de pigmentos fenólicos (antocianinas, flavonóides e protoantocianinas) no vacúolo. A expressão da cor também é influenciada 
por fatores fisicos, como a presença de bolsas de cera, formato e orientação da epiderme e da sub-epiderme. Os pigmentos e a superficie topográfica absorvem e refletem, seletivamente, a luz incidente para produzir o espectro característico de uma fruta ou hortaliça (Lister et al., 1997).

Dornenbrug \& Knorr (1996) identificam quatro grupos de compostos relacionados com a coloração natural de frutas e hortaliças. Os grupos são os benzopiranos (antocianinas, flavonas e flavonóides), os betalinos (betacianina e betantina), os carotenóides (carotenos e xantofilas), as clorofilas e as quinonas. Em contraste, as hortaliças de raízes e os bulbos de cebola contém mais flavonóides (Park \& Lee, 1996; Patil et al., 1995b).

A qüercitina é um bioflavonóide natural e faz parte do grupo dos flavonóides com anéis de benzeno, ligados a um anel heterocíclico de pirina (Crozier et al., 1997; Leighton et al., 1992; Patil \& Pike, 1995). Perkin \& Hummel, em 1896, conforme o citado por Fenwick \& Hanley (1985), já relatavam a presença de qüercitina na casca de cebola do tipo amarela, e também relataram o uso desta casca como tinta, para a pintura de móveis no início do século. Fossen et al. (1998) também relatam que a qüercitina é um dos principais compostos fenólicos presentes em catáfilos de cebola.

Bilyk et al. (1984) observaram a presença de outro flavonóide, kaempferol, em pequena quantidade na casca de cebola. Em algumas cultivares, essa quantidade é cerca de vinte vezes menor do que a quantidade presente de qüercitina. Por sua vez, Crozier et al. (1997) não detectaram o pigmento kaempferol em bulbos de cebola. Outro pigmento, a antocianina, foi detectado em cebolas roxas (Fossen et al., 1996). 
O decréscimo na quantidade de qüercitina da camada externa para a interna foi relatado em vários trabalhos (Bilyk et al., 1984; Fenwick \& Hanley, 1985; Patil \& Pike, 1995). Patil \& Pike (1995) relatam que nos diversos cultivares de cebola estudados, a maior concentração de qüercitina ocorre nas camadas externas e não nas camadas internas (5-6 e 7-10). Hermann em 1976, conforme citação de Patil \& Pike (1995), relata que a síntese de flavonóides requer o estímulo da luz, explicando assim a maior concentração de flavonóides na casca. Como a presença de flavonóides é maior nas escamas externas e na casca, sugere-se que ela é uma barreira natural contra ataques de pragas e insetos (Fenwick \& Hanley, 1985). Isolados da casca de cebola produziram flavonóides, aparentemente, em quantidades maiores do que em bulbos intactos (Fenwick \& Hanley, 1985).

A qüercitina ocorre, principalmente, na casca externa no estado livre e nas outras escamas na forma combinada (Fenwick \& Hanley, 1985). Patil \& Pike (1995) estudando diferentes cultivares de cebola, quanto aos seus teores de qüercitina livre e total (ligada e livre), observaram que a livre é a mais encontrada na casca. Bilyk et al. (1984) também relatam a presença de qüercitina livre na casca de cebolas, em quantidades que variavam de $5 \%$ a $53 \%$ do total. Grande parte dos estudos estão relacionados à qüercitina livre, que oferece maiores beneficios à saúde do que a qüercitina total (Patil et al., 1995b).

Patil \& Pike (1995) estudaram a distribuição de qüercitina livre e total nos bulbos de seis cultivares de cebola (três com coloração de casca amarela, dois com coloração de casca roxa e um com coloração de casca branca). Cebolas com coloração mais intensa contém níveis mais altos de qüercitina do que cebolas brancas. A mais alta concentração 
de qüercitina foi encontrada na casca de cebolas com coloração roxa da cultivar Red Bone (30,66 g/Kg de peso seco), seguida por outra cultivar de coloração roxa, Kadavan, $(27,32 \mathrm{~g} / \mathrm{Kg}$ de peso seco). A menor concentração foi encontrada em bulbos com cor branca, cultivar Contessa $(0,094 \mathrm{~g} / \mathrm{Kg}$ de peso seco). Bilyk et al. (1984), analisando oito cultivares de cebola, observaram a presença de qüercitina, na casca externa dos bulbos em todos de todos os materiais estudados. A maior concentração foi observada no híbrido 'Carmen' (34,15 g/Kg de peso seco). Por sua vez, a cultivar Red Hambuguer, roxa, apresentou a concentração de $6,60 \mathrm{~g} / \mathrm{Kg}$ de peso seco. Não foi observada a presença de qüercitina nos anéis internos da cebola roxa, cultivar Red Hambuguer.

Patil et al. (1995b) determinaram o conteúdo de qüercitina livre (qüercitina glicosídeo) e de qüercitina total em anéis internos de 75 cultivares de cebola (55 amarelos, 3 rosados, 6 roxos e 11 brancos). A concentração de qüercitina total variou de 0,21 a $286 \mathrm{mg} / \mathrm{Kg}$ de peso fresco. A maior concentração de qüercitina total foi encontrada na cebola amarela, da cultivar Sweet Savannah. Cebolas roxas apresentaram concentrações intermediárias e as brancas as menores concentrações. Esses resultados conflitam com os encontrados por Patil \& Pike (1995), e uma das possiveis razões para isto é que no trabalho de Patil et al. (1995b) foram analisadas as porções medianas dos bulbos. Por sua vez, Price et al. (1997) relatam maior concentração de qüercitina em cebolas roxas do que naquelas com casca marrom. Foram analisadas as porções internas do bulbo, excluindo a casca. Tais resultados conflitam com os de Crozier et al. (1997) que, analisando bulbos de cebola após a remoção da casca, constataram maior teor de qüercitina em amostras de cebola branca do que em de cebola roxa. A análise foi 
realizada utilizando-se material de cebola triturado. Leighton et al. (1992) relatam a ausência de qüercitina em cebolas brancas e a sua presença nas roxas e nas com casca de coloração amarela. Patil et al. (1995b) observaram que diferenças podem ocorrer quando as análises foram realizadas em partes do bulbo ou no total.

\subsubsection{Fatores que influenciam a pigmentação da cebola}

Patil et al. (1995b) relacionam que a presença e a concentração de qüercitina podem não estar relacionadas com a coloração dos bulbos, mas a fatores genéticos que determinam essa concentração independentemente da coloração do bulbo. Leighton et al. (1992) descrevem que características genéticas são determinantes na concentração de

qüercitina. Vários autores enumeram os diversos fatores externos que podem afetar a pigmentação em cebola.

\section{Cura}

Patil et al. (1995a) relatam que houve significativo aumento no teor de qüercitina em cebolas curadas a campo, após a colheita. Bulbos de cebola deixados a campo por 34 dias após a colheita mostraram aumento significativo no teor de qüercitina. Hermann (1976), citado por Patil \& Pike (1995), relata que a síntese de flavonóides requer o estímulo da luz, explicando assim a maior concentração de flavonóides na casca. Por sua vez, Price et al. (1997), analisando a porção comestível de cebolas roxas e de casca 
marrom-escura, observaram variações no teor de qüercitina após a cura artificial à $28{ }^{\circ} \mathrm{C}$ por 10 dias. As duas cultivares demonstraram queda no teor de qüercitina total após a cura artificial. Ocorreu uma alteração no teor inicial de qüercitina monoglucosídea de $1004 \mu \mathrm{g} / \mathrm{g}$ de peso fresco, na colheita, para $465 \mu \mathrm{g} / \mathrm{g}$ de peso fresco, após o processo de cura.

\section{Armazenagem}

Patil et al. (1995b) relatam que bulbos armazenados apresentam maior quantidade de qüercitina total. Bulbos foram armazenados a $5{ }^{\circ} \mathrm{C}, 24{ }^{\circ} \mathrm{C}$ e $30{ }^{\circ} \mathrm{C}$, em atmosfera controlada (CA), por $0,1,2,3,4$ e 5 meses. Encontrou-se o maior teor de qüercitina nos bulbos armazenados a $24{ }^{\circ} \mathrm{C}$, com aumento durante os três primeiros meses de armazenagem e um decréscimo no final. Os teores iniciais de qüercitina, nas amostras analisadas, eram de $78,83 \mathrm{mg} / \mathrm{Kg}$ de peso fresco e após três meses de armazenamento a $24{ }^{\circ} \mathrm{C}$, aumentaram para $140,24 \mathrm{mg} / \mathrm{Kg}$ de peso fresco. Uma das razões para o decréscimo nos teores de qüercitina no período final da armazenagem deveu-se a uma maior podridão dos bulbos. Concluiu-se que os fatores genéticos e os de armazenamento afetaram o teor de qüercitina em cebola. Price et al. (1997) também relatam aumento no teor de qüercitina em cebola armazenada por 24 semanas a $4{ }^{\circ} \mathrm{C}$. A variação no teor de qüercitina monoglucosídea não foi estatisticamente diferente, ao variar de 1.045 para $1.323 \mu \mathrm{g} / \mathrm{g}$ de peso fresco. 


\section{Elementos associados à pigmentação}

Hollman et al. (1996) relatam um método para deteç̧ão fluorescente de flavonóides com Al por HPLC. Flavonóides, como qüercitina, podem formar quelatos fluorescentes com uma variedade de íons de metal. Relacionam à interação de $\mathrm{Al}^{-3} \mathrm{com}$ qüercitina, indicando uma afinidade para formação de quelatos entre metais livres e qüercitina. Bankar \& Dara (1982), estudando afinidade de casca de cebola por metais, $\mathrm{Ca}^{++}$e $\mathrm{Mg}^{++}$, relatam grande afinidade de soluções de casca de cebola de coloração

vermelha por esses metais. A pesquisa nesse caso era direcionada para retirada de metais pesados com o objetivo de despoluente.

\section{Outros fatores}

Patil et al. (1995a) relatam variação no teor de qüercitina em cebolas da mesma variedade, desenvolvidas em diferentes localidades. Avaliando o teor de qüercitina em cebolas, com diferentes épocas de plantio observaram um aumento neste teor coincidentemente com a época de menor suprimento em nitrogenados. Também se relacionou neste trabalho que o maior teor de qüercitina em bulbos cultivados, em algumas épocas de plantio pode também estar relacionado à maior intensidade luminosa.

Leighton et al. (1992) relatam que a cultivar Ringo, quando cultivada em diferentes regiões, mostrou variação no teor de qüercitina de $30-40 \%$. Os maiores teores 
ocorreram em regiões sujeitas à seca. Estes autores relacionaram o maior teor de qüercitina com a menor disponibilidade de água.

\subsection{Outros compostos presentes na cebola}

Contrariamente aos flavonóides, os aminoácidos concentram-se nas escamas internas do bulbo. A concentração do aminoácido arginina é $27 \%$ menor nas escamas externas quando comparadas às internas (Fenwick \& Hanley, 1985).

Extratos da casca de cebolas de coloração vermelha apresentaram maior conteúdo de compostos fenólicos do que extratos de casca de cebola branca. Essa maior concentração de compostos fenólicos em cebolas vermelhas está relacionada à maior resistência a doenças, em especial a fungos parasiticos (Fenwick \& Hanley, 1985).

A casca de cebola também apresenta alta concentração de substâncias pécticas, o que permite sua utilização para fins industriais (Fenwick \& Hanley, 1985). Alexander \& Sulebele (1973) relatam que a concentração de pectina na casca de cebola em 9,2\% do peso seco para a branca, e $7,1 \%$ do peso seco, para a roxa.

Poucos estudos foram realizados sobre conteúdo de lipídeos na casca de cebola. Sallan et al. (1974) relatam que esteróides (sterol) representam $26 \%$ da fração lipidea de cebolas pigmentadas. 


\subsection{Efeito da nutrição no desenvolvimento da planta, qualidade do bulbo e formação da casca}

Grande parte das pesquisas realizadas com hortaliças são com os macronutrientes, N, P, K, Ca, Mg e S. Todavia, atenção especial tem sido dada aos micronutrientes, B, $\mathrm{Cl}, \mathrm{Cu}, \mathrm{Fe}, \mathrm{Mn}$, Mo e $\mathrm{Zn}$, são elementos essenciais, e em geral, em pequenas quantidades (gramas/hectare). As fontes destes micronutrientes são as mais diversas, havendo aquelas rapidamente solúveis, tais como o ácido bórico e o sulfato de cobre, e aquelas mais lentamente solúveis como o esterco animal. O esterco animal é importante fonte de micronutrientes, não prontamente disponíveis (Malavolta et al., 1974).

$\mathrm{O} \mathrm{pH}$ do solo também é importante para o desenvolvimento da cebola. Fontes (1980) relata que a cebola é uma planta muito sensível à acidez do solo, e que valores de $\mathrm{pH} 6,0-6,5$ são ideais para o desenvolvimento desta cultura. Knott (1933) relata que cebolas desenvolvidas em condições de solo muito ácido apresentam casca mais fina. Por outro lado, a coloração não foi afetada por solos muito ácidos.

A adubação da cebola tem muita influência na formação dos bulbos. Excesso na adubação nitrogenada podem causar bulbos mal formados, de maturação mais tardia e que apresentam altas perdas durante a armazenagem. A deficiência em $\mathrm{N}$ leva a bulbos pequenos e antecipa a colheita (Bender, 1993; Churata-Masca \& Canalez, 1988). Brewster \& Butler (1989) relatam que a aplicação de nitrogenados, no início da cultura e não no fim, retardam a bulbificação e a formação da casca. Baixo níveis de nitrogenados resultam em baixa taxa de crescimento das folhas e maior demora para iniciar a formação 
das escamas do bulbos. Este trabalho utilizou condições de fotoperiodo limítrofes às necessárias (Brewster \& Butler, 1989).

A deficiência em $\mathrm{P}$ também influencia a qualidade do bulbo. Plantas deficientes apresentam colheita mais tardia e alta presença de plantas taludas "thick-necks" (Bender, 1993). Knott (1933), em experimentos em solos turfosos, relata que a aplicação de superfosfato $(16 \%$ de $\mathrm{P})$ em altas dosagens $(5.037 \mathrm{~kg} / \mathrm{ha})$ auxiliou no aumento da espessura da casca e na acentuação da coloração da casca de cebola. Altas dosagens produziram cebolas de coloração mais escura. O fornecimento de $\mathrm{P}$ anteriormente a esta pesquisa era em menor quantidade, pois produtores utilizavam-se somente da fórmula 28-10, na metade da dose citada acima.

Os micronutrientes, $\mathrm{Cu}$ e $\mathrm{B}$, estão relacionados com à qualidade dos bulbos e com a formação e a coloração da casca, enquanto que o macronutriente $\mathrm{Ca}$ influencia na formação da parede celular.

Nelson et al. (1956), estudando diversas culturas hortícolas quanto a deficiência em $\mathrm{Cu}$, relatam que cebola é extremamente sensível à carência desse nutriente. A aplicação no plantio, de óxido de $\mathrm{Cu}$ em solos arenosos, na dose de $25 \mathrm{~kg} / \mathrm{ha}$, proporcionou aumento de $22 \%$ na produtividade quando comparado com a testemunha. Murphy \& Walsh (1973) descrevem que a cultura da cebola possui alta resposta a aplicações de $\mathrm{Cu}$. Por sua vez, Knott (1933), trabalhando com solos turfosos, não observou aumento na produtividade, mas alteração em outros caracteres, como espessura da casca e coloração do bulbo. Haag et al. (1982) relatam que a deficiência em Cu pode ocorrer em solos arenosos; em solos alcalinos, sujeitos à calagem excessiva; solos 
turfosos; e em solos ácidos e lixiviados. $\mathrm{O}$ íon cobre $\left(\mathrm{Cu}^{\top-}\right)$ é facilmente fixado na forma de complexos orgânicos (Marschner, 1986).

$\mathrm{Na}$ planta, o primeiro sintoma de deficiência em $\mathrm{Cu}$ surgem nas folhas mais novas. Estas tornam-se menos espessas e com pouca firmeza, com aparência seca, e coloração amarelo-parda. Com o aumento da deficiência, aparecem a clorose e a necrose na ponta das folhas novas, que evoluem ao longo das margens. O crescimento cessa e em alguns casos, ocasiona a morte das plantas (Fernandes, 1971; Haag et al., 1982; Murphy \& Walsh, 1973). Bender (1993) relata que a deficiência em $\mathrm{Cu}$ pode afetar em muito a qualidade dos bulbos de cebola. As escamas externas ficam finas e com baixa pigmentação, resultando em bulbos com pouca coloração. Purvis \& Carolus (1951) descrevem que aplicações de $\mathrm{Cu}$ proporcionaram aumento na espessura da casca e alterações na coloração da casca, que passa de amarela para marrom-brilhante. Fernandes (1971) relata que pulverizações com $\mathrm{Cu}$ levaram a aumento na qualidade dos bulbos e na produção da cebola. Aplicações de $\mathrm{Cu}$ também induziram a maturação precoce.

Knott (1933) desenvolveu pesquisa com esta cultura em solos orgânicos no Estado de Nova York, EUA, onde os bulbos apresentavam boas características para comercialização, mas cascas com coloração mais clara e espessura fina. Em alguns casos, $50 \%$ da produção era descartada devido a esses problemas. Baixa retenção e fina espessura da casca ocorreriam independentemente da coloração da casca.

A pesquisa de Knott (1933) baseou-se em relato de produtores que produziam bulbos com boa coloração de casca nas seguintes condições: (a) solos orgânicos 
intensamente cultivados e submetidos a altas adubações em culturas anteriores. (b) solos que mantinham bom nível de umidade; (c) solos que foram previamente cultivados com batata. (d) culturas pulverizadas contra insetos. Relacionou-se, então, esses fatos com alguma deficiência mineral e os trabalhos foram realizados em casa de vegetação e campo.

Knott (1933) relata que a aplicação de sulfato de $\mathrm{Cu}$ em solos turfosos, anterior ao plantio, proporcionou aumento na espessura da casca e incrementou a coloração dos bullbos. Quanto à dosagem, $112 \mathrm{~kg}$ de sulfato de $\mathrm{Cu} / \mathrm{ha}$ já proporcionam aumento na espessura e maiores dosagens não proporcionaram aumento significativo nesta espessura. De um total de 18 experimentos de campo, 11 que utilizaram-se da dosagem de $224 \mathrm{~kg}$ de sulfato de $\mathrm{Cu}$ /ha proporcionaram significativo aumento na espessura da casca e na coloração dos bulbos. Em alguns campos, essa dosagem não proporcionou incremento na coloração da casca, o que foi relacionado à baixa umidade do solo. A dosagem de $224 \mathrm{~kg}$ de sulfato de $\mathrm{Cu} / \mathrm{ha}$, em casa de vegetação, também proporcionou o mesmo resultado. Mesmo com a aplicação de sulfato de $\mathrm{Cu}$, algumas variedades não apresentaram aumento na espessura da casca, mas mostraram coloração acentuada.

A firmeza dos bulbos também foi incrementada nos tratamentos com aplicação de sulfato de $\mathrm{Cu}$. Bulbos provenientes de cultivo convencional, sem aplicações de sulfato de $\mathrm{Cu}$, sofriam injúrias quando pressionados pelas mãos. Por sua vez, bulbos de campos que receberam este sulfato demonstravam maior firmeza e não sofriam de injúria pelas mãos.

Altas dosagens de sulfato de cobre afetam a coloração e a espessura dos catáfilos dos bulbos de cebola, mas não interferiram na produtividade. Todavia, cascas finas e 
com coloração mais clara podem ocorrer em campos que apresentam alta produtividade (Knott, 1933).

Por sua vez, Ellerbrock (1997), trabalhando com solos turfosos, em 49 campos de produção, no Estado de Nova York, EUA, não encontraram resposta a aplicações de sulfato de $\mathrm{Cu}$, via solo, tanto para a produtividade como para a qualidade do bulbo. Como parâmetros de qualidade foram utilizados a coloração, a retenção e a espessura da escama externa. Essa falta de resposta a aplicação do sulfato de $\mathrm{Cu}$ deve-se principalmente ao fato que os agricultores daquele estado americano utilizam, há muitos anos como prática para melhoria da coloração dos bulbos, a aplicação anual de 100 $\mathrm{Kg} / \mathrm{ha}$ de $\mathrm{CuSO}_{4}$. Nesse estudo não foram detectados sinais de toxidez por $\mathrm{Cu}$.

A deficiência em B pode ocorrer em qualquer estádio de desenvolvimento da planta, como resultado do excesso de irrigação e de chuvas pesadas, calagem excessiva de solos ácidos e secas prolongadas (Malavolta et al., 1974). A deficiência pode ocorrer também, com mais freqüência, em solos pobres em matéria orgânica ou em condições de seca prolongada, em que a mineralização da matéria orgânica, uma das principais fontes fornecedoras de B, é dificultada (Haag et al., 1982).

Haag et al. (1982) relatam que a deficiência de B, em plantas hortícolas, se caracteriza-se pela paralisação do crescimento e a morte do tecido meristemático. As folhas apresentam tonalidade verde-azulada e, posteriormente uma textura coriácea e quebradiça. Há paralisação do crescimento e morte das folhas a partir do ápice (Fernandes, 1971; Purvis \& Carolus, 1951). O crescimento das raízes é bastante reduzido (Haag et al., 1982; Marschner, 1986). 
Calbo et al. (1986), trabalhando com a cultivar Baia Periforme, relatam a deficiência de $\mathrm{B}$ afetando os bulbos de cebola, prejudicando sua aparência e seu armazenamento. A deficiência em B reduziu o "tombamento" ou "estalo" das plantas e o peso médio dos bulbos. Bulbos apresentaram sintomas de necrose interna mais intensa ao redor do ponto de crescimento e escamas duras e enrugadas com aspecto de material desidratado. Observou-se uma variação na formação das escamas da cebola. Bulbos normais apresentaram a epiderme formada por uma camada de células homogêneas, contínuas e alongadas, revestidas por uma cutícula fina. Por sua vez, bulbos deficientes mostraram células epidérmicas de forma cúbica e desprovidas de cutícula. A desidratação ocorrida nessas escamas pode ter sido em conseqüência dessa ausência de cutícula. Os bulbos deficientes apresentaram-se, no final do período de armazenagem, cerca de $70 \%$ podres, enquanto que as plantas que receberam tratamento com B $12 \%$ de bulbos podres.

Plantas de cebola submetidas a altas dosagens de $\mathrm{B}$, não apresentaram efeitos significativos na redução do diâmetro e no peso dos bulbos (Francois, 1991). Submeteuse a cebola a soluções nutritivas de 0,$5 ; 1,0 ; 5,0 ; 10,0 ; 15,0 ;$ e 20,0 mg B/L. Plantas de cebola foram cultivadas em tanques de areia com suprimento de nutrientes periódicamente. A concentração de boro nas folhas e no bulbo relacionou-se diretamente com a concentração da solução utilizada. Altas concentrações em B não afetaram os níveis de $\mathrm{K}, \mathrm{Ca}, \mathrm{Mg}, \mathrm{P}$ e Na nas folhas e bulbos.

O cálcio atua na estrutura da membrana plasmática e na parede celular. $\mathrm{Ca}$, assim como B, funciona fora do citoplasma, no apoplasto (Marschner, 1986). A presença de 
Ca é essencial para a manutenção da permeabilidade seletiva da membrana, assim como para a manutenção da sua integridade. Este ion providencia ligações intramoleculares estáveis, mas reversíveis, entre moléculas de pectina, resultando em rigidez da parede celular. A presença de $\mathrm{Ca}^{++}$extracelular faz a ligação entre a parede celular e a membrana plasmática $\mathrm{O}$ fluxo de $\mathrm{K}^{+}$em plantas expostas a injúria por frio é altamente reduzida na presença de Ca extracelular (Palta, 1996).

Marschner (1986) relata que pulverizações foliares com $\mathrm{Ca}$, durante o desenvolvimento de frutos, ou com a imersão dos mesmos em solução com $\mathrm{CaCl}_{2}$, aumentam a firmeza e previne o amadurecimento.

Fenn et al. (1993) observaram a influência de aplicações de Ca, durante diferentes pontos de crescimento da cebola, na absorção de $\mathrm{NH}_{4}$ e conseqüente desenvolvimento dos bulbos. Aplicações de cálcio influenciaram o aumento na mobilidade dos metabólitos das raizes, indicando um aproveitamento mais eficiente do N. Foram estudadas diferentes dosagens da relação $\mathrm{Ca}^{++}: \mathrm{NH}_{4}{ }^{-}$, ou sejam, $0 ; 0,25 ; 0,50 ; 1,00$ e 2,00, aplicadas via solução nutritiva, por um período de 30 horas em três diferentes épocas: 38,60 e 134 dias após a germinação. Observou-se que as aplicações de $\mathrm{Ca}$, aos 38 e 134 dias proporcionaram aumento no crescimento dos bulbos, em especial na primeira época, assim como a translocação de metabólitos e $\mathrm{N}$ das raizes. $\mathrm{Na}$ segunda época esse efeito não foi significativo. Na primeira época, o aumento o para peso seco do bulbo, para alguns tratamentos, foi até de $100 \%$, e na terceira época foi de $28 \%$, para alguns tratamentos. A aplicação de Ca no início do ciclo proporcionou um maior crescimento 
da planta e dos bulbos e elevado teor em $\mathrm{N}$ na parte aérea e nos bulbos, do que a sua aplicação mais tardia.

\subsection{Injúria e armazenagem em cebola}

A injúria no bulbo de cebola pode ser superficial ou interna. A injúria na superficie é mais facilmente detectada do que as internas. A injúria deve quebrar as membranas externas, mas algumas vezes pode ficar somente nas partes internas do bulbo e não estar exposta (Maw et al., 1995). Toledo et al. (1984) relatam que bulbos pequenos demonstravam maior firmeza que os bulbos graúdos e que a firmeza varia durante armazenagem. No início, a força de compressão para medição da firmeza é de 30 Newtons e após armazenagem por 4 meses, foi necessária uma força de compressão de 27,1 Newtons. Tratamentos na pré-colheita, como a aplicação de hidrazida maléica, o desfolhamento com paraquat e o corte das ramas, não afetaram a firmeza dos bulbos.

$\mathrm{Na}$ cura da cebola, as películas externas e o pseudocaule devem ser secos. A cura torna os bulbos mais resistentes a danos e à entrada de microorganismos, aumenta o período de conservação, melhora a qualidade comercial da cebola e as condições para armazenamento (Matos, 1987).

A maior capacidade de armazenamento aparenta estar ligada a três principais características: percentagem de sólidos solúveis, alta pungência e dormência longa (Apeland, 1971). 
Alta umidade relativa $(75-80 \%)$ é extremamente prejudicial para o armazenamento da cebola, assim como a baixa umidade $(65 \%)$ pois causa perda de umidade do bulbo. A umidade relativa ideal é a de 65-75\% (Brice et al. 1997).

A temperatura ideal para armazenamento pode variar de $0-5{ }^{\circ} \mathrm{C}$ ou de $25-30{ }^{\circ} \mathrm{C}$. A brotação é favorecida em temperaturas que variam de $5-20{ }^{\circ} \mathrm{C}$, dependendo da cultivar. Hardenburg et al. (1986) indica que a cebola pode ser armazenada por até 8 meses, em temperaturas de $0{ }^{\circ} \mathrm{C}$. Em temperaturas entre $5-20{ }^{\circ} \mathrm{C}$, dependendo da cultivar, há relatos de armazenagem por até 60 dias.

Brice et al. (1997) descrevem três métodos de armazenamento: (1) Ventilação Natural: método mais simples que utiliza ventilação natural, sem ventiladores ou equipamentos afins; (2) Ventilação Forçada: uso de equipamentos apropriados para isso, como ventiladores; (3) Ventilação forçada seguida de ar condicionado: utilização especial de ar frio para refrigeração. 


\section{MATERIAL E MÉTODOS}

Ensaios de campo foram instalados na estação experimental de hortaliças da Seminis Vegetable Seeds - SVS do Brasil Sementes Ltda, em Paulínia (SP), localizada na latitude $22^{\circ} 54^{\circ} \mathrm{S}$ e longitude $47^{\circ} 05^{\circ} \mathrm{W}$, e altitude de 660 metros acima do nivel do mar, nos anos de 1997 e 1998. O solo dessa propriedade é classificado como Latossolo Vermelho Amarelo-LVA, fase arenosa.

O Experimento 1 foi instalado em julho de 1997, e o Experimento 2, em julho de 1998, em outra área de cultivo próxima à anterior. Nos dois ensaios a campo, a retirada de amostra do solo para análise foi feita anteriormente ao plantio, seguindo-se as recomendações descritas por Raij et al. (1996). A análise de solo foi realizada pelo Laboratório de Análises de Solos do Departamento de Solos e Nutrição de Plantas, da Escola Superior de Agricultura "Luiz de Queiroz", ESALQ, da Universidade de São Paulo.

\subsection{Experimento 1 (ano de cultivo 1997)}

Foram utilizadas três variedades e três híbridos, provenientes do programa de cebolas tropicais da empresa SVS do Brasil Sementes Ltda. O sistema de cultivo e os 
tratos culturais utilizados foram os tradicionalmente observados pelos produtores de cebola.

Em 1997, como pode ser observado na Tabela 1, o inverno não foi rigoroso, com temperaturas minimas acima de $11{ }^{\circ} \mathrm{C}$. Outra característica importante referente a esse ano de cultivo foi que a colheita ocorreu no início do mês de novembro, tendo-se o cuidado de evitar as maiores concentrações de chuvas nesse mês.

TABELA 1. Médias mensais de temperatura (máxima, mínima e média) e totais de chuva medidas no posto metereológico da Estação Experimental de Hortaliças SVS, durante o período de cultivo do Experimento 1, ano de 1997

\begin{tabular}{|c|c|c|c|c|}
\hline \multirow[b]{2}{*}{ Meses } & \multicolumn{3}{|c|}{ Temperatura } & \multirow[b]{2}{*}{$\begin{array}{l}\text { Precipitação } \\
\text { (mm) }\end{array}$} \\
\hline & $\begin{array}{l}\text { Máxima } \\
\left({ }^{\circ} \mathrm{C}\right)\end{array}$ & $\begin{array}{l}\text { Mínima } \\
\left({ }^{\circ} \mathrm{C}\right)\end{array}$ & $\begin{array}{l}\text { Média } \\
\left({ }^{\circ} \mathrm{C}\right)\end{array}$ & \\
\hline Abril & 29,5 & 14,4 & 21,95 & 17,0 \\
\hline Maio & 26,5 & 12,7 & 19,60 & 62,0 \\
\hline Junho & 24,3 & 11,0 & 17,65 & 136,3 \\
\hline Julho & 27,5 & 11,6 & 19,55 & 0,0 \\
\hline Agosto & 28,7 & 10,5 & 19,6 & 10,0 \\
\hline Setembro & 29,9 & 15,6 & 22,75 & 73,0 \\
\hline Outubro & 30,8 & 17,0 & 23,90 & 70,0 \\
\hline Novembro & 31,1 & 19,8 & 25,48 & 188,9 \\
\hline
\end{tabular}

\subsubsection{Produção das mudas}

Para a produção das mudas de cebola, o terreno foi previamente arado e gradeado e os canteiros construídos com $1,0 \mathrm{~m}$ de largura por $15 \mathrm{~cm}$ de altura, com enxada rotativa, no sentido transversal ao declive. Os canteiros possuíam $25 \mathrm{~m}$ de comprimento e corredores com $50 \mathrm{~cm}$ de largura. Neste Experimento, não se realizou tratamento sanitário anterior à semeadura. Em cada canteiro, foram riscadas 8 linhas no sentido 
longitudinal. A semeadura foi manual, realizada em 5 de maio, e a densidade utilizada foi a de $3 \mathrm{~g}$ de semente $/ \mathrm{m}^{2}$ de canteiro. Após a semeadura, as sementes foram cobertas, utilizando-se bagacilho de cana devidamente curtido. Semeou-se $10 \mathrm{~g}$ de cada cultivar e as cultivares eram separadas uma das outras, nos canteiros, pela distância de $20 \mathrm{~cm}$. Utilizou-se como fonte de adubo orgânico, esterco de galinha curtido, na dose de 1 $\mathrm{kg} / \mathrm{m}^{2}$. A adubação mineral foi de $100 \mathrm{~g}$ de fertilizante, $4-14-8$, por $\mathrm{m}^{2}$ de canteiro. A adubação de cobertura foi realizada aos 30 dias após a semeadura, utilizando-se sulfato de amônio na dosagem de $15 \mathrm{~g}$ por $\mathrm{m}^{2}$. A capina sempre foi manual, a irrigação por aspersão e as pulverizações com inseticidas e fungicidas iniciaram-se logo após a emergência, utilizando-se na fase de produção das mudas as dosagens praticadas pelos produtores e as recomendadas pelos fabricantes. Utilizaram-se os fungicidas Benlate (Benomyl), 200 g/100 L, em duas pulverizações; Rovral (Iprodione), 150 g/ 100 L, em uma pulverização e a mistura Recop (oxicloreto de cobre), 200 g/100 L, e Dithane PM (Mancozeb), 200 g/100 L, também em uma pulverização. Foram usadas, uma aplicação de cada um dos inseticidas, Folisuper 600 BR (Parathion Metil), $100 \mathrm{ml} / 100 \mathrm{~L}$; Confidor 700 GRDA (Imidacloprid), na dosagem de 100 g/100 L; Dicarzol 500 PS (Formetanate Hidrocloreto), $25 \mathrm{ml} / 100 \mathrm{~L}$ e Karate $50 \mathrm{CE}$ (Lambdacyhalothrin), $50 \mathrm{ml} / 100 \mathrm{~L}$. No canteiro de mudas ainda foram realizadas três pulverizações, com o adubo foliar, PlantFal, $100 \mathrm{~g} / 100 \mathrm{~L}$ que apresenta a seguinte formulação, $\mathrm{K} 10 \%, \mathrm{Mg} 1 \%$, Zn 8\%, B 3\%, $\mathrm{Fe} 2 \%, \mathrm{Mn} 2 \%$, Cu 0,5\% e Mo 0,2\%. 


\subsubsection{Produção a campo}

O terreno para transplante foi previamente arado e gradeado e os canteiros levantados utilizando-se enxada rotativa.

A análise do solo (Tabela 2) permitiu estabelecer a fertilidade do mesmo, assim como planejar as adubações; os valores apresentados foram interpretados segundo Raij et al. (1996), permitindo observar os altos teores de micro e macronutrientes neste solo.

TABELA 2. Análise química do solo (0-20 $\mathrm{cm}$ de profundidade) anterior ao plantio, do local do Experimento 1 (1997), na Estação Experimental de Hortaliças SVS.

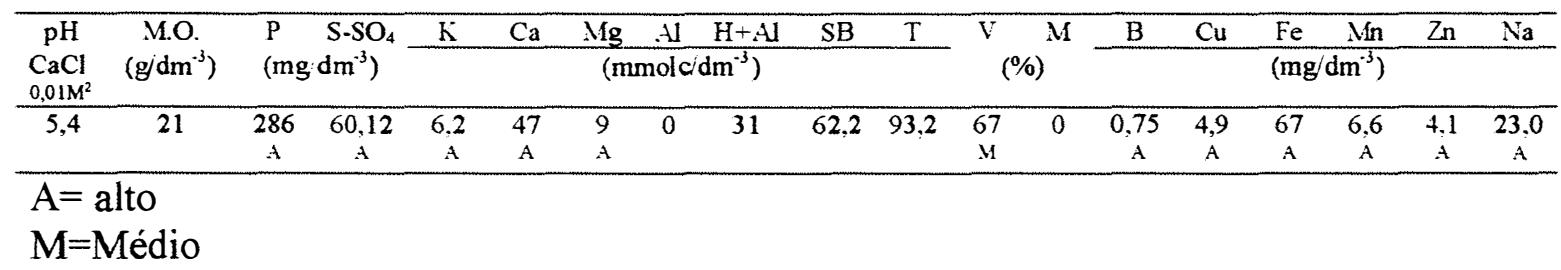

A adubação mineral e orgânica realizada após a construção dos canteiros, empregou esterco de galinha curtido, $2.000 \mathrm{~kg} / \mathrm{ha}$ e o fertilizante $4-14-8$, na quantidade de $1.000 \mathrm{~kg} / \mathrm{ha}$. Após esta aplicação, realizou-se a incorporação com a enxada rotativa.

O transplante ocorreu 60 dias após a semeadura. As mudas antes de serem transplantadas foram previamente selecionadas e as ramas cortadas, utilizando-se somente um padrão determinado, com cerca de $20 \mathrm{~cm}$ de comprimento. O espaçamento utilizado para plantio foi de $25 \mathrm{~cm}$ entre linhas e de $8 \mathrm{~cm}$ entre plantas.

Foram utilizadas 4 repetições, constando de 50 plantas cada, as quais foram separadas no campo por um espaço de $20 \mathrm{~cm}$. A adubação de cobertura ocorreu aos 50 
dias após o transplante utilizando-se sulfato de amônio na dosagem de $300 \mathrm{~kg} / \mathrm{ha}$. As plantas, durante o cultivo, receberam pulverizações com os fungicidas RidomilMancozeb (Metalaxyl + Mancozeb), 300 g/100 L, 1 aplicação; Fungiscan 700 PM (Tiofanato Metílico), 70 g/100 L, 4 aplicações; Dithane PM (Mancozeb), 200 g/100 L, 2 aplicações; Rovral (Iprodione), 200 g/100 L, 2 aplicações; Benlate 500 (Benomyl), 200 g/100 L, 2 aplicações. O fungicida Recop (Oxicloreto de Cobre), 200 g/100 L, também foi utilizado após o primeiro mês em 2 pulverizações.

O cultivo em 1997, foi caracterizado por uma grande incidência de Tripes (Thrips tabaci), que exigiu portanto aplicações semanais e alternadas dos seguintes inseticicas: Danimen 300 CE (Fenpropathrin), $150 \mathrm{ml} / 100 \mathrm{~L}$; Dicarzol 500 PS (Formetanate Hidrocloreto), 25 g/100 L; Lorsban 480BR (Chlorpyrifos), 150 ml/100 L; Confidor 700 GRDA (Imidacloprid), 100 g/100 L; Karate 50 CE (Lambdacyhalothrin), $50 \mathrm{ml} / 100 \mathrm{~L}$; Decis $25 \mathrm{CE}$ (Deltamethrine), $30 \mathrm{ml} / 100 \mathrm{~L}$ e FoliSuper $600 \mathrm{BR}$ (Parathion methyl), $100 \mathrm{ml} / 100 \mathrm{~L}$.

O controle das plantas daninhas foi feito aplicando-se, duas semanas após o transplante, o herbicida Afalon SC (Linuron), 1,5 1/ha, para controle em pré-emergência de plantas daninhas de folha larga e para controle de folhas estreitas, em pós-emergência o herbicida Fusilade 125 (Fluazifop-p-butil), 1,5 1/ha. As dosagens utilizadas foram sempre as praticadas pelos produtores e recomendadas pelos fabricantes.

A irrigação foi por aspersão, em um total de 2 horas de irrigação por semana, divididos em 3 vezes na semana, utilizando-se o bico aspersor, AgroPolo, especificação $6 \times 5$, distanciado de $18 \mathrm{~m}$ cada um. 
O ponto de colheita utilizado foi o tradicionalmente usado por produtores, ou seja, quando $50-60 \%$ das plantas estavam estaladas. Por ter sido um inverno/primavera com altas temperaturas, o estalo e a maturação dos bulbos de todos os materiais foram coincidentes.

\subsubsection{Materiais genéticos}

As cultivares selecionadas para este experimento apresentam origem e coloração de casca diferenciadas. Utilizou-se as variedades Serrana, Régia e Crioula. A variedade Serrana, com casca de coloração clara; a 'Régia', com casca mais escura que a anterior e a 'Crioula', com presença de maior número de escamas e de coloração marrom-escura. Utilizaram-se também dois híbridos simples, HS-1 e HS-2, e um híbrido triplo HT. Os híbridos simples são provenientes do cruzamento de distintas linhas macho-estéreis, tipo Baia Periforme, com presença de cascas claras, utilizando como polinizador a variedade Crioula. O híbrido triplo é proveniente do cruzamento de um híbrido $F_{1}$, utilizando-se como polinizador a variedade Crioula. O híbrido $F_{1}$, provém de um cruzamento entre duas linhagens, de populações tipo Baia Periforme. 


\subsubsection{Tratamentos}

Foram utilizados quatro tratamentos no Experimento 1:

Tratamento 1: testemunha.

Tratamento 2: oxicloreto de cobre na dosagem de $250 \mathrm{~g} / 100 \mathrm{~L}$ de água.

Tratamento 3: ácido bórico na dosagem de 250 g/100 L de água.

Tratamento 4: combinação dos tratamentos 2 e 3.

As aplicações foram feitas em diferentes épocas: início da bulbificação (uma aplicação), meio da bulbificação (duas aplicações) e fim da bulbificação (uma aplicação). As pulverizações iniciaram em 10 de outubro de 1997 e finalizaram em 31 de outubro de 1997. Como fonte de oxicloreto de $\mathrm{Cu}$ utilizou-se o fungicida Recop, Sandoz S.A., e como fonte de ácido bórico utilizou-se o ácido bórico solúvel, $17 \%$ B, ProduQuímica Industria e Comércio Ltda. As pulverizações foram realizadas com o pulverizador costal Jacto, 20 L. No momento da aplicação em campo, utilizou-se um anteparo constituido de papelão comum, para se evitar a deriva de produtos. A colheita ocorreu em 6 de novembro de 1997, uma semana após o termino das pulverizações. As plantas foram retiradas do campo e secas em ambiente semi-sombreado. Após uma semana, as ramas foram cortadas e iniciaram-se as análises. 


\subsubsection{Armazenamento}

Os bulbos foram armazenados à temperatura ambiente $\left(25^{\circ} \mathrm{C}\right)$ em delineamento experimental com blocos casualisados, na Estação Experimental de Hortaliças SVS, durante período superior a 90 dias após a colheita. Os bulbos foram acondicionados em caixas plásticas ventiladas.

\subsubsection{Delineamento estatístico.}

O delineamento experimental utilizado foi o de blocos inteiramente casualisados em esquema de parcela subdivididas, sendo as parcelas composta pelos tratamentos e as subparcelas pelos materiais genéticos, utilizando-se 4 repetições, contendo 50 plantas cada. A análise da variância permitiu verificar o efeito dos fatores (tratamento, cultivar e interação) e a comparação entre as médias foi feita pelo teste de Tukey, ao nível de significância de 5\%. Em todas as análises, realizou-se o teste de normalidade e homogeneidade das variâncias sobre os dados, para verificação das pressuposições do modelo.

\subsection{Experimento 2 (ano de cultivo 1998)}

O Experimento 2 foi conduzido de forma semelhante ao Experimento 1, utilizando-se as mesmas técnicas para a produção de mudas e cultivo a campo. Diferenças ocorreram, descritas a seguir. Conforme o mostrado pela Tabela 3 , houve 
uma maior concentração de chuvas no mês de outubro, diferentemente do ano anterior. Em relação à temperatura, o mês de outubro, talvez devido à maior pluviosidade também apresentou temperaturas mais amenas que o correspondente período no ano anterior.

TABELA 3. Médias mensais de temperatura (máxima, mínima e média) e totais de chuva, medidas no posto metereológico da Estação Experimental de Hortaliças SVS, durante o periodo de cultivo do Experimento 2, ano 1998.

\begin{tabular}{lcccc}
\hline \multirow{2}{*}{ Meses } & \multicolumn{3}{c}{ Temperatura } & Máxima \\
\cline { 2 - 4 } & $\left({ }^{\circ} \mathrm{C}\right)$ & $\begin{array}{c}\text { Mínima } \\
\left({ }^{\circ} \mathrm{C}\right)\end{array}$ & $\begin{array}{c}\text { Média } \\
\left({ }^{\circ} \mathrm{C}\right)\end{array}$ & $\begin{array}{c}\text { Precipitação } \\
(\mathrm{mm})\end{array}$ \\
\hline Abril & 28,8 & 15,5 & 22,15 & 52,0 \\
Maio & 26,2 & 12,6 & 19,40 & 107,5 \\
Junho & 25,7 & 10,2 & 17,95 & 19,0 \\
Julho & 27,5 & 10,6 & 19,05 & 0,0 \\
Agosto & 29,4 & 14,1 & 21,75 & 12,0 \\
Setembro & 29,8 & 16,2 & 23,0 & 82,0 \\
Outubro & 27,7 & 16,9 & 22,3 & 144,3 \\
Novembro & 30,8 & 16,9 & 23,85 & 48,2 \\
\hline
\end{tabular}

\subsubsection{Produção de mudas}

Utilizou-se para a produção de mudas o mesmo processo de preparo e construção dos canteiros. A diferença em relação ao Experimento 1, no ano de 1997, foi a realização do tratamento dos canteiros aplicando-se o fumigante de solo, Basamid (Dazomet), após o levantamento dos canteiros e adubação, na dosagem de $50 \mathrm{~g} / \mathrm{m}^{2}$. Os canteiros, depois da distribuição e incorporação do fumigante com a enxada rotativa foi irrigado até a capacidade de campo. Após a irrigação, ele foi coberto com plástico transparente aditivado, $100 \mu$, durante 30 dias. Após esse período retirou-se a cobertura plástica e a semeadura ocorreu uma semana depois. 
O processo de semeadura, a densidade de plantio e o tipo de cobertura morta foram os mesmos utilizados no ano anterior. A semeadura ocorreu em 4 de maio de 1998, e o transplante em 5 de julho. A adubação orgânica e mineral dos canteiros foram as mesmas utilizadas no Experimento 1. A adubação de cobertura foi realizada 25 dias após a semeadura, utilizando-se sulfato de amônio na dosagem de $15 \mathrm{~g} / \mathrm{m}^{2}$.

A capina dos canteiros foi manual e a irrigação foi por aspersão. As pulverizações com inseticidas e fungicidas iniciaram-se logo após a semeadura, utilizando-se os mesmos fungicidas, inseticidas e adubos foliares usados no Experimento 1, observando-se a não aplicação do fungicida Recop (oxicloreto de cobre), e que a segunda pulverização com o fungicida Benlate (Benomyl), foi substituída, pelo tratamento em banho de imersão, por 1 minuto, em uma mistura do fungicida Benlate (Benomyl), $100 \mathrm{~g} / 100 \mathrm{~L}$ de água, com o inseticida Confidor, (Imidacloprid), $30 \mathrm{~g} / 100 \mathrm{~L}$ de água, após o arranquio e corte das ramas.

\subsubsection{Produção a campo}

O transplante foi realizado aos 61 dias após a semeadura e os tratos culturais utilizados foram semelhantes aos do ano anterior. A análise do solo foi realizada antes do cultivo e os resultados (Tabela 4) permitiram estabelecer a fertilidade do mesmo, assim como planejar as adubações. Os valores apresentados foram interpretados segundo Raij et al. (1996), permitindo observar de maneira semelhante ao já observado para o Experimento 1, os altos teores em micro- e macronutrientes neste solo. 
TABELA 4. Análise química do solo $(0-20 \mathrm{~cm}$ de profundidade $)$ anterior ao plantio do local do experimento 2. (1998), na Estação Experimental de Hortaliças SVS.

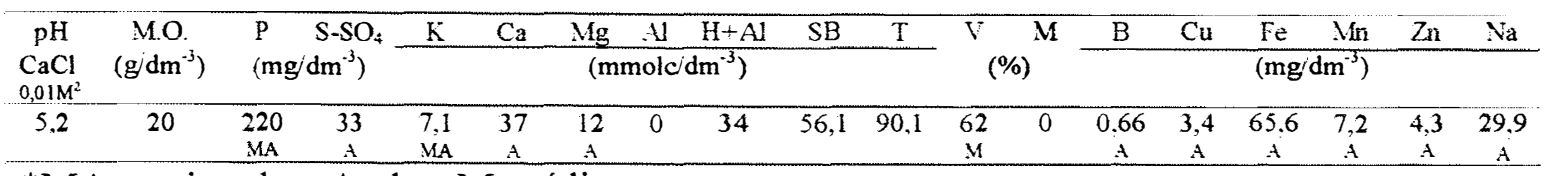

*MA- muito alto; A-alto; M-médio.

A adubação mineral e orgânica realizada após a construção do canteiro, foram as mesmas usadas no ensaio anterior, com a incorporação, através de enxada rotativa. As mudas a serem transplantadas também eram previamente selecionadas e as ramas cortadas utilizando-se o mesmo padrão para plantio, determinado no ano anterior. Utilizou-se o mesmo espaçamento entre plantas e linhas e a adubação de cobertura ocorreu aos 55 dias após o transplante utilizando-se uréia na dose de $150 \mathrm{~kg} / \mathrm{ha}$. As pulverizações com fungicidas foram semelhantes às do ano anterior. Neste Experimento 2, ocorreu uma maior incidência de Míldio, Peronospora destructor, o que levou ao uso dos fungicidas Folio (Metalaxyl + Chlorotalonil), 300 g/ 100 L; Vanox 500 SC (Chlorotalonil), $200 \mathrm{ml} / 100 \mathrm{~L}$; assim como um maior número de pulverizações com o fungicida Ridomil Mancozeb BR (Metalaxyl + Mancozeb), $300 \mathrm{~g} / 100 \mathrm{~L}$. O fungicida Dithane PM (Mancozeb), 200 g/100 L, com exceção das aplicações com Ridomil Mancozeb BR, que já contém este princípio ativo, foi utilizado em todas aplicações com fungicidas. Não foi aplicado nenhum fungicida cúprico em pulverizações a campo.

O ano de 1998, diferentemente do ano anterior, foi caracterizado por uma menor incidência do Tripes, Thrips tabaci. As pulverizações com inseticidas tiveram início 1 mês após o transplante, com a seguinte sequiência de inseticidas: Dicarzol 500 PS (Formetanate hidrocloreto), $25 \mathrm{~g} / 100 \mathrm{~L}$; Confidor 700 GRDA (Imidacloprid), 100 
ml/100 L; FoliSuper 600 BR (Parathion methyl), $100 \mathrm{ml} / 100 \mathrm{~L}$ e Hamidop 600 (Methamidophós), $100 \mathrm{ml} / 100 \mathrm{~L}$. Utilizaram-se as dosagens recomendadas pelo fabricante.

Para controle de plantas daninhas, em contraste ao ano anterior, aplicou-se o herbicida Ronstar 250 BR (Oxadiazon) em pré-emergência, 10 dias após o transplante, dosagem de 1,5 1/ha. Em pós-emergência das plantas daninhas de folha estreita utilizouse o herbicida Fusilade 125 (Fluazifop-p-butil), 1,5 1/ha. As doses utilizadas foram as recomendadas pelos fabricantes. A irrigação a campo foi por aspersão, na mesma periodicidade empregada para o ensaio anterior. Utilizou-se o mesmo padrão para ponto de colheita do ensaio do ano anterior.

\subsubsection{Materiais genéticos}

Com base na análise dos resultados obtidos em 1997, utilizou-se neste ensaio a variedade Serrana, de casca clara; 'Crioula', de casca de coloração escura e o híbrido simples, HS-1. 


\subsubsection{Tratamentos}

Foram utilizados os seguintes tratamentos:

Tratamento 1: testemunha

Tratamento 2: oxicloreto de $\mathrm{Cu}$ na dosagem de $250 \mathrm{~g} / 100 \mathrm{~L}$ de água.

Tratamento 3: ácido bórico na dosagem de $250 \mathrm{~g} / 100 \mathrm{~L}$ de água.

Tratamento 4: cloreto de Ca na dosagem de $100 \mathrm{~g} / 100 \mathrm{~L}$ de água.

Foram efetuadas três pulverizações: a primeira no início, a segunda no meio e a terceira no fim da bulbificação. As aplicações foram semanais, iniciando-se em 2 de outubro e finalizando em 16 de outubro de 1998. As aplicações foram realizadas seguindo-se o mesmo método utilizado no Experimento 1, em 1997. Ao contrário do ano anterior, o estalo das diferentes cultivares e do híbrido ocorreu em épocas distintas. A colheita da variedade Serrana e do híbrido HS-1 realizou-se em 20 de outubro e a da variedade Crioula, duas semanas após.

\subsubsection{Armazenamento}

Os bulbos foram armazenados à temperatura ambiente $\left(25^{\circ} \mathrm{C}\right)$ em delineamento experimental com blocos casualizados, na Estação Experimental de Hortaliças SVS, durante periodo superior a 90 dias após a colheita. Os bulbos foram acondicionados em caixas plásticas ventiladas. 


\subsubsection{Delineamento estatítico}

O delineamento experimental utilizado foi o de blocos inteiramente casualisados em esquema de parcela subdivididas, sendo as parcelas compostas pelos tratamentos e as subparcelas pelos materiais genéticos, utilizando-se 4 repetições, contendo 50 plantas cada. Como no experimento do ano anterior foi realizada a análise da variância para verificar o efeito dos fatores (tratamento, cultivar e interação) e posteriormente a comparação entre as médias pelo teste de Tukey ao nível de 5\%. Em todas as análises realizou-se o teste de normalidade e homogeneidade das variâncias sobre os dados, para verificação das pressuposições do modelo.

\subsection{Coleta de dados biométricos}

Periodicamente durante o armazenamento, foram acompanhadas as alterações fisico-químicas nos bulbos de cebola mediante a medição de alguns parâmetros, a saber: perda de peso, diâmetro, resistência da casca, firmeza e coloração da casca.

\subsubsection{Perda de peso}

A perda de peso $(\%)$ foi estudada pela relação entre a diferença entre o peso inícial e o final, dividido pelo peso inicial e multiplicada por 100. As pesagens iniciaram após o termino da cura, e o peso inicial utilizado referia-se sempre à última medição. As pesagens foram realizadas e m balança de precisão, Marte, excluindo-se as 
perdas em virtude de deterioração e da brotação. Utilizou-se a média de cinco bulbos para cada repetição.

\subsubsection{Diâmetro}

Foram realizadas nas mesmas datas das avaliações para peso, utilizando-se um paquímetro, com as medidas tomadas na altura mediana de cada bulbo. Utilizou-se a média de cinco bulbos para cada repetição. Estas avaliações foram realizadas somente no Experimento 1.

\subsubsection{Resistência da casca}

A resistência da casca também foi determinada no Laboratório Central do Departamento de Planejamento Alimentar e Nutrição da Faculdade de Engenharia de Alimentos, da Universidade Estadual de Campinas, UNICAMP. Para esta determinação também utilizou-se texturômetro Stable Micro Systems, Godalming, Surrey, United Kingdon. A medida foi destrutiva e realizada no ponto mediano sobre o equador de cada bulbo. Nesse teste de ruptura, utilizou-se uma sonda de formato pontiagudo, modelo SMS P/2N, com uma força constante de $0,20 \mathrm{~N}$, até a profundidade máxima de penetração de $0,3 \mathrm{~mm}$. Cada repetição foi composta de cinco bulbos. A espessura máxima $(0,3 \mathrm{~mm})$ foi baseada na média da casca externa das variedades e híbridos em estudo. 


\subsubsection{Firmeza}

A análise de firmeza foi realizada no Laboratório Central do Departamento de Planejamento Alimentar e Nutrição da Faculdade de Engenharia de Alimentos, Universidade Estadual de Campinas, UNICAMP. Para este teste utilizou-se texturômetro Stable Micro Systems, Godalming, Surrey, United Kingdom realizada no ponto mediano sobre o equador de cada bulbo. Utilizou-se uma sonda de formato esférico, modelo P/0-55, com diâmetro de $1 \mathrm{~cm}$, à qual se aplicou uma força constante de $0,20 \mathrm{~N}$, até a profundidade máxima de $10 \mathrm{~mm}$. Cada repetição foi composta pela média de cinco bulbos.

\subsubsection{Cor}

A cor externa foi determinada em colorímetro Hunter Lab - Color Quest II ${ }^{\mathrm{TM}}$ II Sphere, Color Quest ${ }^{\mathrm{TM}} 45 / 0$ LabScan $^{\mathrm{R}}$, MiniScan $^{\mathrm{TM}}$, Hunter Associates Laboratory, Inc. Reston, Virginia, USA. Esta medida visou avaliar as alterações na cor dos bulbos durante o armazenamento. Utilizou-se para cada repetição a média de cinco bulbos. As medições foram realizadas no mesmo bulbo, na parte mediana e em faces opostas, durante o período de armazenagem. A escala $\operatorname{CIELAB}\left(\mathrm{L}^{*}, \mathrm{a}^{*}, \mathrm{~b}^{*}\right)$ foi utilizada. A cor é relatada por 3 diferentes parâmetros integralizados em um diagrama tridimensional que mostra a coloração do produto. $\mathrm{L}^{*}$ varia de 0 a 100 , em que o valor 0 indica o preto e o valor 100 , o branco. Valor a* varia do vermelho $\left(+a^{*}\right)$, localizado a $0^{\circ}$ ou $360^{\circ}$, ao verde $\left(-a^{*}\right)$, que está a $180^{\circ}$ (na ausência dos componentes amarelo ou azul). $O$ valor $b^{*}$, na 
ausência dos componentes verde ou vermelho, varia do amarelo $\left(+b^{*}\right)$, e azul $\left(-b^{*}\right)$, que estão a $90^{\circ}$ e $270^{\circ}$ respectivamente. (Shewfelt et al., 1988). Medições de coloração foram expressas em termos de valor (L), ângulo hue $\left(\tan ^{-1} b^{*} / a^{*}\right)$ e chroma $\left(a^{*^{2}}+b^{*^{2}}\right)^{1 / 2}$ (McGuire, 1992, Shewfelt et al., 1988).

$L^{*}:$ O parâmetro $L^{*}$ indica a variação da coloração de preta a branca, em uma escala de 0 a 100 . Alto valor de $L^{*}$ representa branco a claro (100), baixo valor de $L^{*}$ representa coloração escura a preta (0). Amadurecimento de frutos é acompanhado por uma coloração mais escura, ou seja, decréscimo do valor L* (Lancaster et al., 1997; Shewfelt et al., 1988).

Ângulo hue: $\mathrm{O}$ ângulo hue, mostra a localização da cor em um diagrama, aonde o ângulo $0^{\circ}$ representa vermelho puro, o $90^{\circ}$ representa o amarelo puro, o de $180^{\circ}$ o verde puro e o $270^{\circ}$ o azul. Amadurecimento de frutos envolve alteração no valor de hue. Por exemplo, em tomate ocorre o aumento da coloração vermelha ou decréscimo no ângulo hue (Shewfelt et al., 1988).

Chroma: Definido como a intensidade ou saturação de cor e é definido pela distância do ângulo hue do centro do diagrama tridimensional. Por exemplo: coloração pastel possui baixa saturação, enquanto uma cor pura possui alta saturação. Chroma aumenta a medida que os frutos amadurecem (McGuire, 1992; Shewfelt et al., 1988). 


\section{RESULTADOS E DISCUSSÃO}

\subsection{Experimento 1 (ano de cultivo 1997)}

\subsubsection{Perda de peso}

Foram realizadas duas avaliações relativas a perda de peso, aos 25 e 45 dias após a colheita. A colheita dos bulbos ocorreu em 6 de novembro e a primeira pesagem dos mesmos ocorreu dez dias após, com a segunda 15 dias após esta, e a terceira 20 dias após esta última.

Os resultados apresentados na Tabela 5 mostram que somente na primeira avaliação, 25 dias após a colheita, os bulbos das plantas tratadas com oxicloreto de $\mathrm{Cu}$ na dosagem de $250 \mathrm{~g} / 100 \mathrm{~L}$ de água, apresentaram menor perda em peso, que os produzidos pelas plantas que receberam tratamento com ácido bórico, $250 \mathrm{~g} / \mathrm{L}$ de água, e pela testemunha. A combinação, ácido bórico e oxicloreto de $\mathrm{Cu}$, mostrou a maior perda em peso. $\mathrm{Na}$ avaliação feita aos 45 dias os tratamentos não mostraram efeito significativo. Não se detectou interação entre o efeito dos tratamentos e os materiais genéticos.

Na primeira avaliação, a menor perda de peso foi observada nos bulbos cujas plantas receberam o tratamento com oxicloreto de cobre, o que pode estar relacionado à 


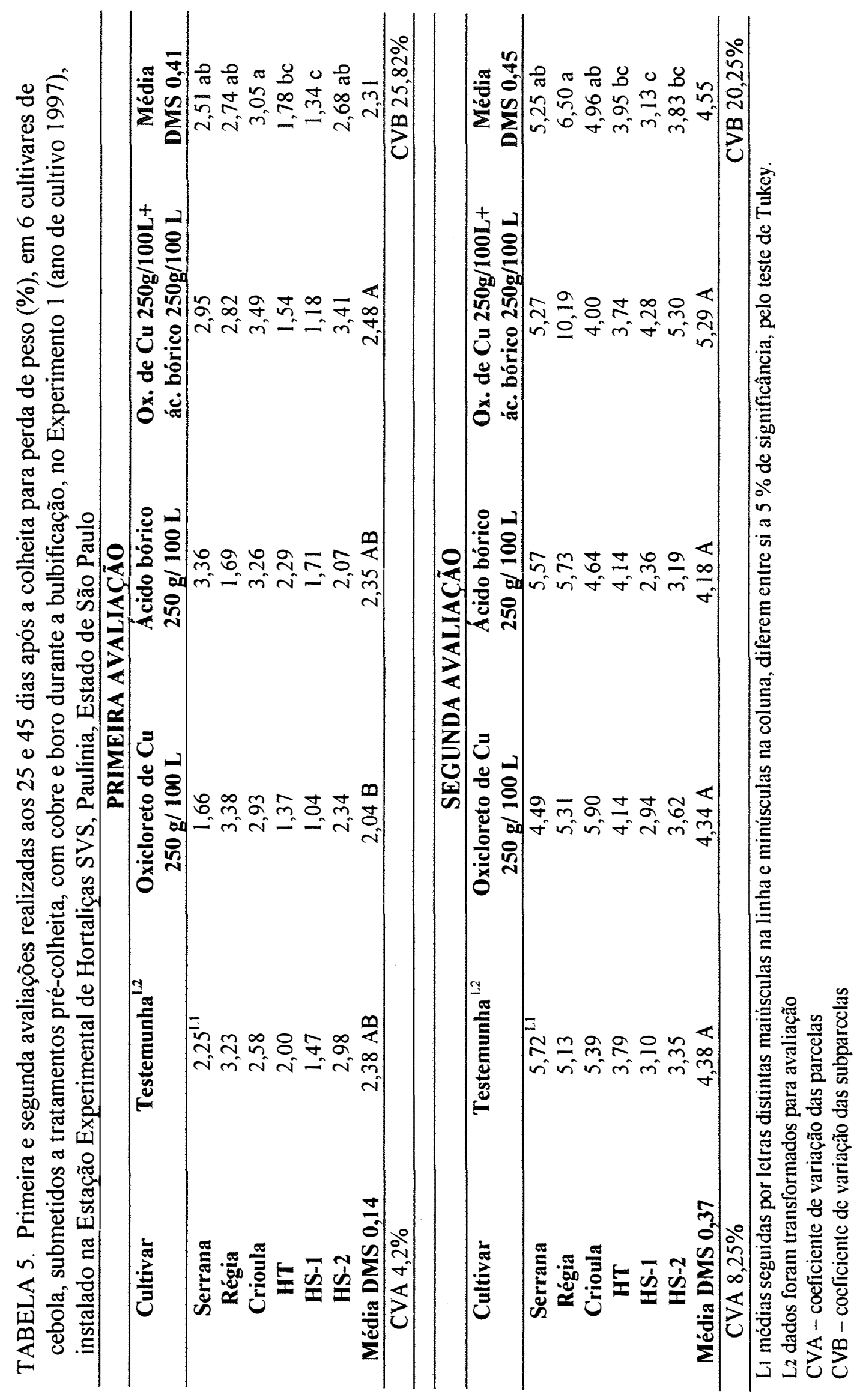


maior resistência e espessura da casca. Knott (1933) relaciona a aplicação de Cu com aumentos da espessura e aderência da casca e da firmeza do bulbo. A casca da cebola funciona como uma barreira contra a perda de água. Sem a casca, a perda de peso durante armazenagem pode dobrar (Apeland, 1971).

As cultivares, para perda de peso, podem ser divididas por uma escala em que os bulbos da 'Crioula', 'Régia', 'Serrana' e híbrido HS-2 perderam mais peso, e os híbridos HT e HS-1 perderam menos peso, nas duas épocas de avaliação. A maior perda em peso para a variedade Crioula, na primeira avaliação, pode estar relacionada ao ponto de colheita, pois todas as cultivares foram colhidas na mesma época e como a 'Crioula' possui ciclo mais tardio que as outras, ela não estava totalmente "madura" e pode ter provocado a maior perda após 25 dias. Por sua vez, o híbrido HS-1 apresentava um excelente e uniforme estalo, o que pode ter contribuído para a menor perda. Este híbrido é proveniente do cruzamento da variedade Crioula com uma linhagem macho-estéril baia-periforme. Para perda de peso, o híbrido diferiu totalmente da variedade polinizadora.

\subsubsection{Diâmetro}

As avaliações para diâmetro foram realizadas aos 10, 25 e 45 dias após a colheita. Utilizou-se o paquímetro na porção mediana dos bulbos. Estão sendo apresentados somente os dados referentes a primeira e terceira avaliação (Tabela 6). Observa-se que não houve diferença estatística entre os tratamentos para o diâmetro médio dos bulbos nas duas avaliações. A variedade Régia nas duas avaliações 


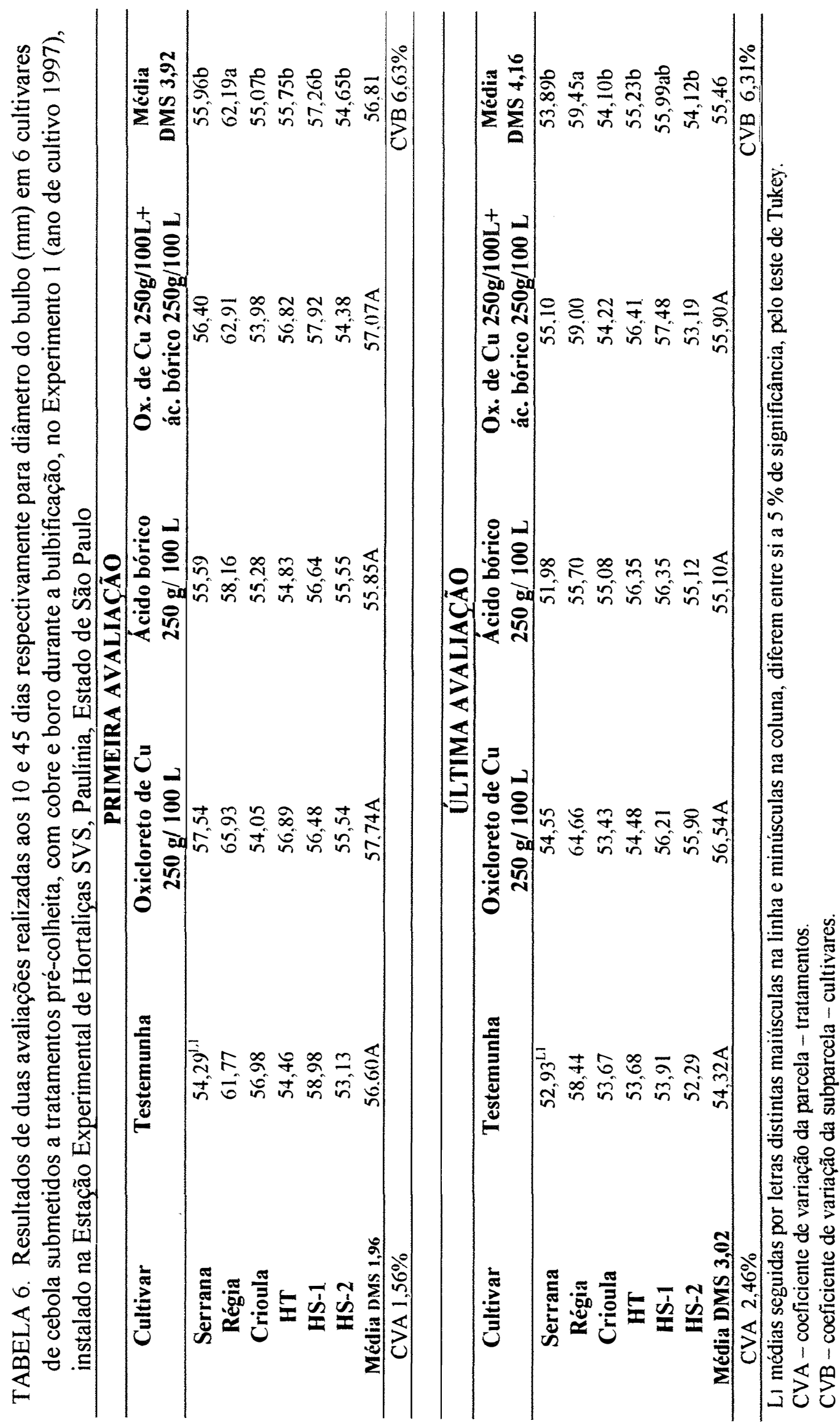


apresentou o maior diâmetro, pois possui como característica bulbos graúdos. Na última avaliação o híbrido HS-1 demonstrou diâmetro inferior a variedade Régia e superior as demais cultivares.

Comparando a primeira e a última avaliação, observa-se que a maior perda em diâmetro ocorreu na testemunha, $4,02 \%$. Os demais tratamentos demonstraram menores perdas em diâmetro que a testemunha. O tratamento com oxicloreto de $\mathrm{Cu}$ apresentou perda em diâmetro de 2,07\%.

\subsubsection{Resistência da casca}

Para medir a resistência da casca, as medições foram realizadas no texturômetro, utilizando-se o teste de ruptura (força medida em Newtons). A primeira avaliação ocorreu 40 dias após a colheita e a segunda avaliação ocorreu 70 dias após a colheita. Pela Tabela 7 observa-se que para a primeira avaliação, 40 dias após a colheita, bulbos tratados com oxicloreto de $\mathrm{Cu}, 250 \mathrm{~g} / 100 \mathrm{~L}$ de água, necessitaram de uma maior força para penetração na casca, portanto demonstrando uma maior resistência, diferindo estatisticamente dos demais. Vários autores descrevem que aplicações via solo com sulfato de $\mathrm{Cu}$, proporcionam um aumento na aderência e espessura da casca (Bender, 1993; Knott, 1933). O tratamento com ácido bórico resultou na segunda maior força para penetração na casca e pela análise estatistica valor intermediário aos demais. B possuí alta influência na formação da casca da cebola (Calbo et al., 1986). A testemunha e o tratamento proveniente da associação entre oxicloreto de $\mathrm{Cu}$ e ácido bórico, demonstraram uma menor resistência das camadas 


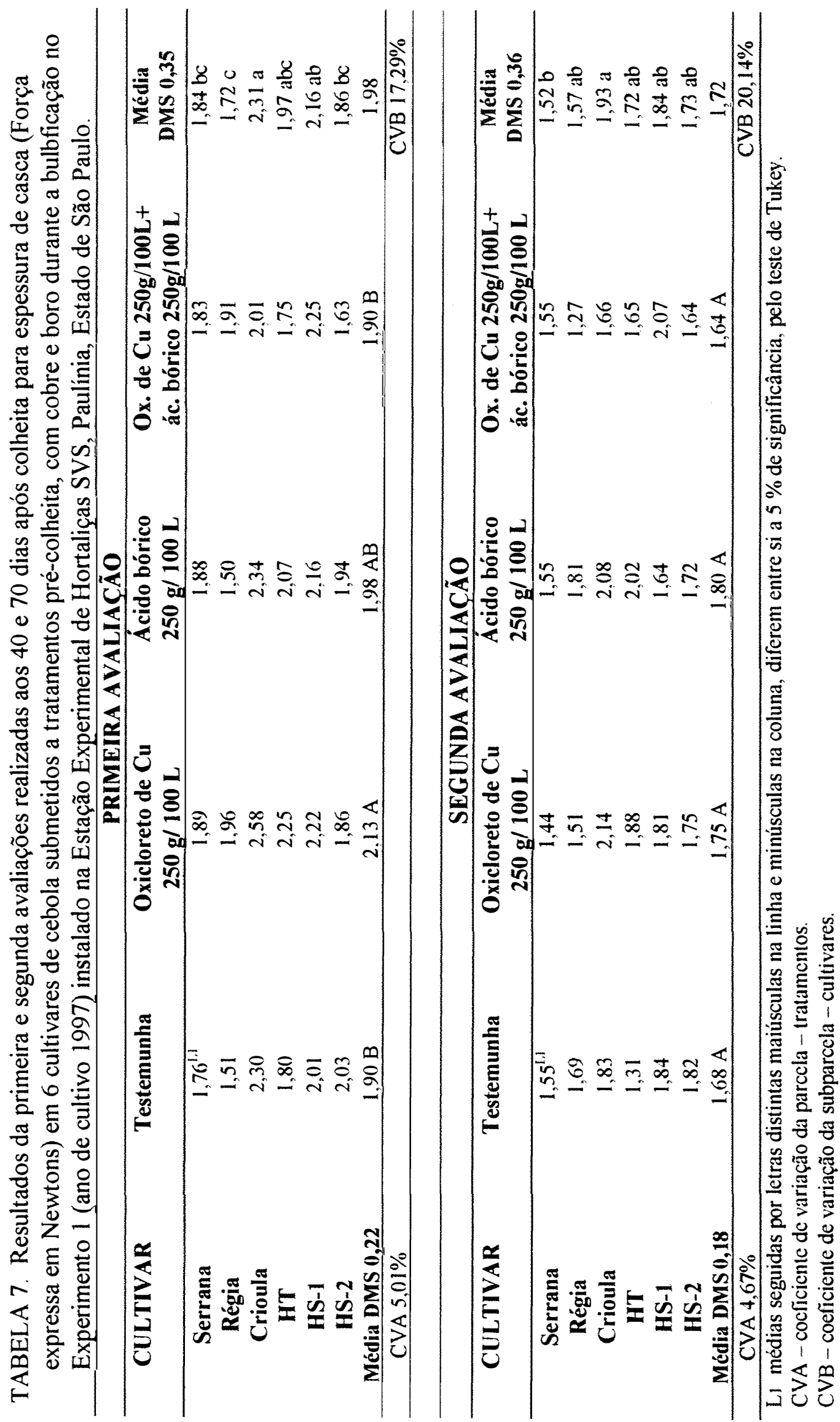


externas. Esses resultados confirmam o efeito dos tratamentos com micronutrientes para espessura da casca.

Em relação as cultivares utilizadas, a variedade Crioula, sabidamente conhecida pela sua película externa, demonstrou a maior resistência a penetração, seguida pelos hibridos HS-1 e HT. A variedade Régia demonstrou a menor resistência à penetração, o que deve estar relacionada à baixa conservação do material e, portanto a um fácil desprendimento das películas externas. Doruchowski (1986a) relata que a espessura de casca mostrou baixo coeficiente de herdabilidade e alta variabilidade entre as linhagens para essa característica. Observou-se alta influência do ambiente para essas características. Outro parâmetro relacionado a casca estudado por esse autor foi aderência da casca. Para esse parâmetro sugere-se uma dominância parcial dos materiais com casca mais aderente nos hibridos $F_{1}$. Linhagens de alta variabilidade para essa caracteristica demonstraram nos híbridos $F_{1}$, alta variabilidade e alta influência às mudanças ambientais. Para obtenção de híbridos com casca bem aderida, o autor sugere que ambos os parentais possuam essa característica. Nesta avaliação observou-se que dois híbridos, no qual 'Crioula' foi utilizada como polinizadora apresentaram maior resistência da casca.

Para a segunda avaliação (Tabela 7), os tratamentos utilizados não demonstraram efeitos significativos para aumento da resistência da camada externa após um periodo prolongado de armazenamento, superior a 70 dias. A média da força utilizada na segunda medição para ruptura da casca foi cerca de $13 \%$ menor do que na primeira medição. Essa perda de resistência e aderência das películas externas nas condições tropicais durante o armazenamento é descrita e observada por produtores. A variedade 
Crioula continuou apresentando maior resistência da camada externa. Os híbridos HS-1, HS-2 e HT e a variedade Régia apresentaram valores intermediários. As variedade Serrana apresentou a menor resistência da camada externa.

\subsubsection{Firmeza}

Para se medir a firmeza dos bulbos submetidos aos diferentes tratamentos, as análises foram realizadas com a seguinte periodicidade: 10,25, 60 e 70 dias após a colheita. As medições foram realizadas no texturômetro, através do teste de compressão e a força medida em Newtons. Nas quatro avaliações das diferentes épocas citadas não se observou resposta para os tratamentos utilizados (Tabelas 8 e 9). Os resultados encontrados conflitaram com os observados por Knott (1933) em que aplicações com sulfato de $\mathrm{Cu}$ aumentaram a firmeza dos bulbos.

As variedades e híbridos apresentaram diferentes respostas para o teste de compressão, demonstrando uma variação entre a cultivares quanto à firmeza dos bulbos.

Na primeira avaliação, 10 dias após a colheita, a variedade Crioula e o híbrido HS-1 apresentaram bulbos com maior firmeza, diferindo significativamente das demais. Na segunda, 25 dias após a colheita, essa diferença foi notadamente observada somente para a 'Crioula' (Tabela 8). Na terceira avaliação, 60 dias após a colheita, a variedade Crioula continuou apresentando bulbos mais firmes que as demais variedades, mas não diferindo estatisticamente dos híbridos. Esses resultados repetiram-se na quarta avaliação, 70 dias após a colheita. Doruchowski (1986a) descreve analisando híbridos $F_{1}$, que menor herdabilidade foi demonstrada para o parâmetro firmeza (32-48\%). Por 


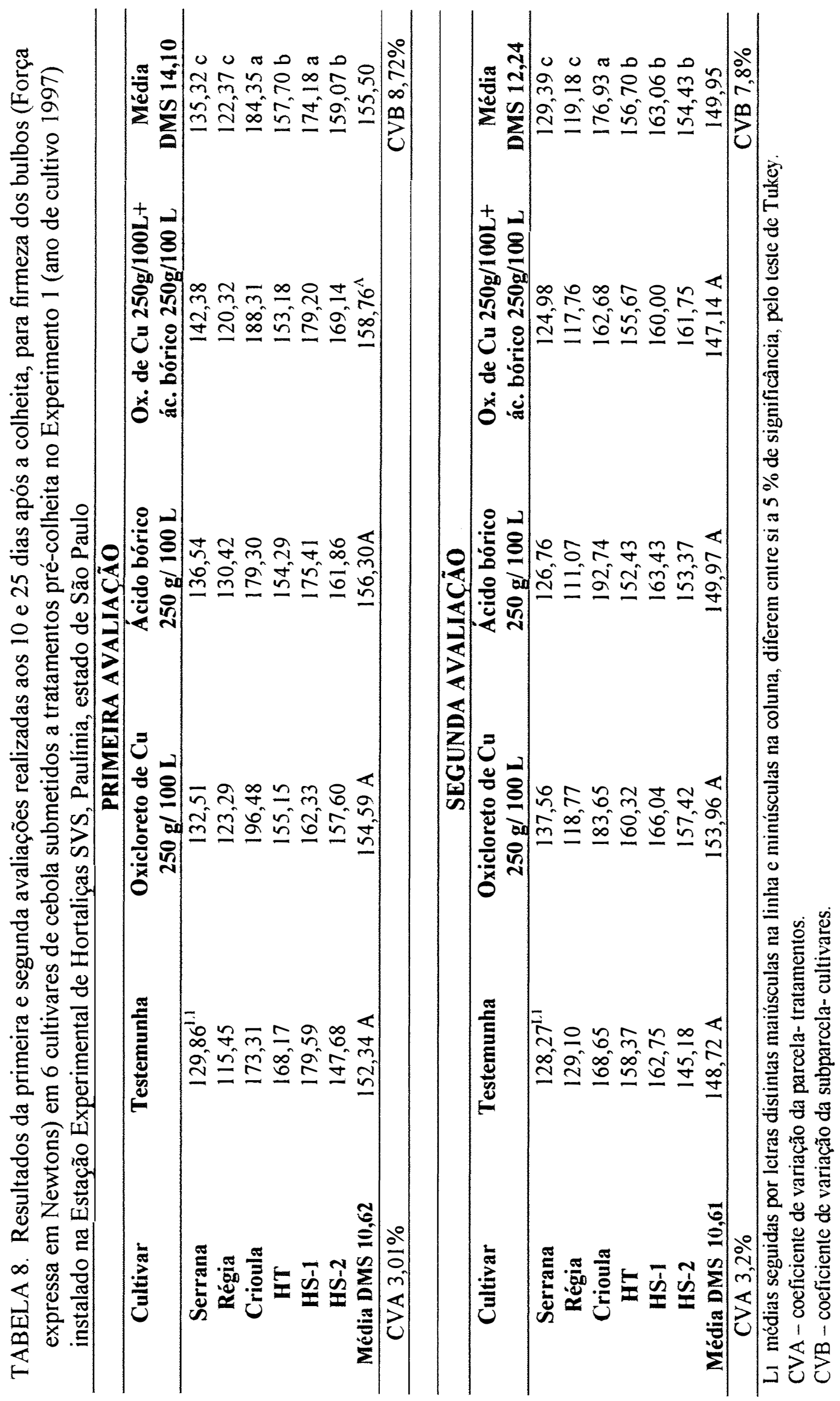




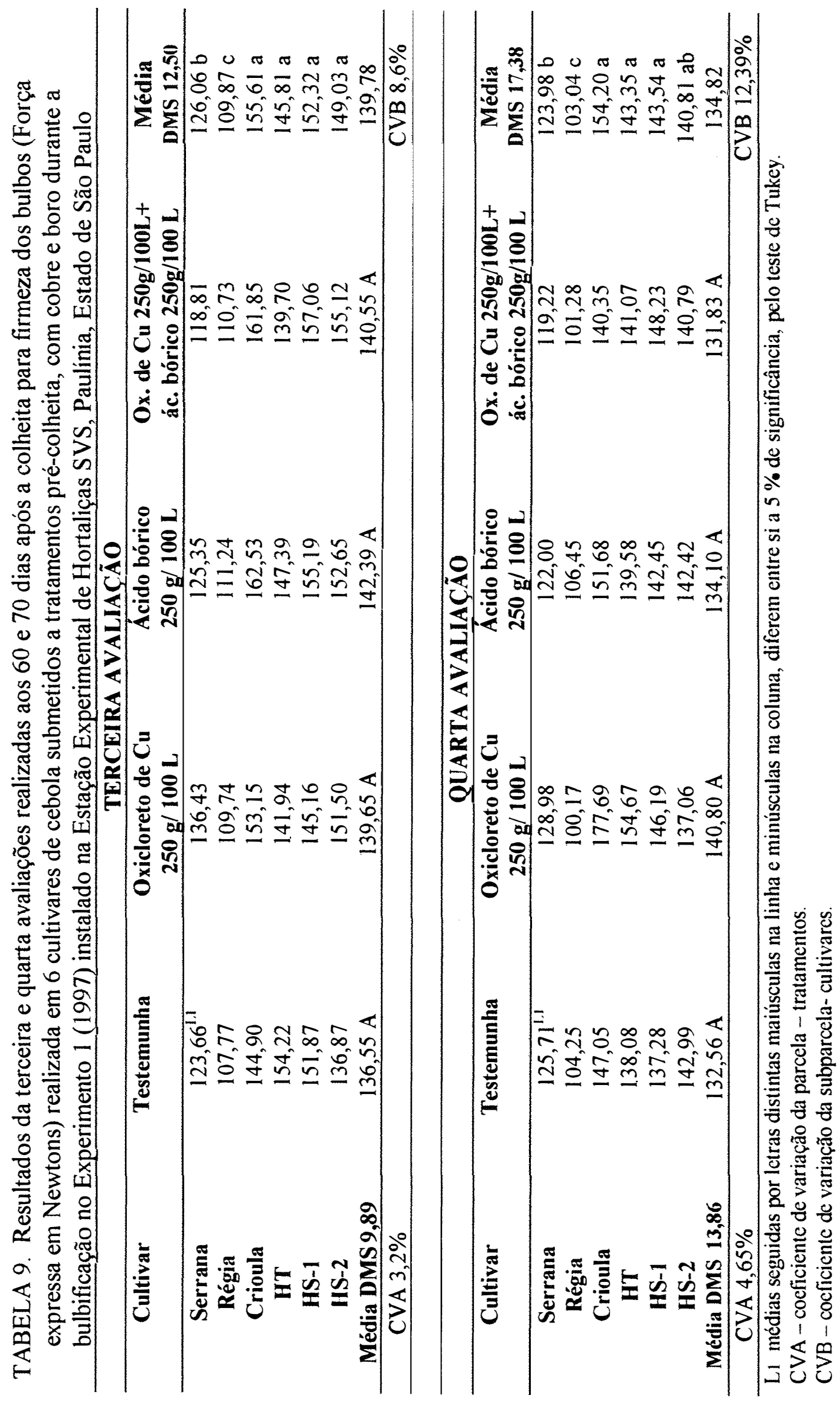


sua vez, observa-se que os híbridos provenientes do cruzamento utilizando-se 'Crioula' como polinizadora demonstram bulbos firmes, quando comparado à variedades, 'Serrana' e 'Régia'.

\subsubsection{Cor}

Para coloração dos bulbos foram realizados três avaliações, aos 7, 40 e 60 dias após a colheita. A cor dos bulbos esta expressa através dos parâmetros $\mathrm{L}$, ângulo hue e chroma.

$\mathrm{Na}$ primeira avaliação, 7 dias após a colheita, os resultados apresentados nas Tabelas 10 e 11, mostram que não houve diferença significativa para os parâmetros L, ângulo hue e chroma nos tratamentos utilizados. A não resposta aos tratamentos utilizados pode estar relacionada ao pouco tempo de armazenamento, pois durante armazenagem ocorre aumento no teor de qüercitina (Patil et al., 1995b).

Em relação às cultivares, 'Crioula' apresentou um menor valor de L (Tabela 10), demonstrando, portanto, bulbos de coloração mais escura, enquanto que a 'Serrana' apresentou bulbos com maior valor de L, e portanto com coloração mais clara. 'Crioula' apresentou menor valor do ângulo hue, indicando bulbos de coloração próxima à vermelha, os híbridos apresentaram valores intermediários, enquanto que 'Serrana' e 'Régia' demonstraram os maiores valores para hue, ou seja coloração de casca mais próxima ao amarelo. O híbrido HS-1, apresentou maior valor de chroma, seguido pela 'Crioula' (Tabela 11), portanto bulbos com coloração mais intensa. A coloração dos bulbos esta relacionada a fatores genéticos (Doruchowski, 1986a; Patil et al., 1995b) e 


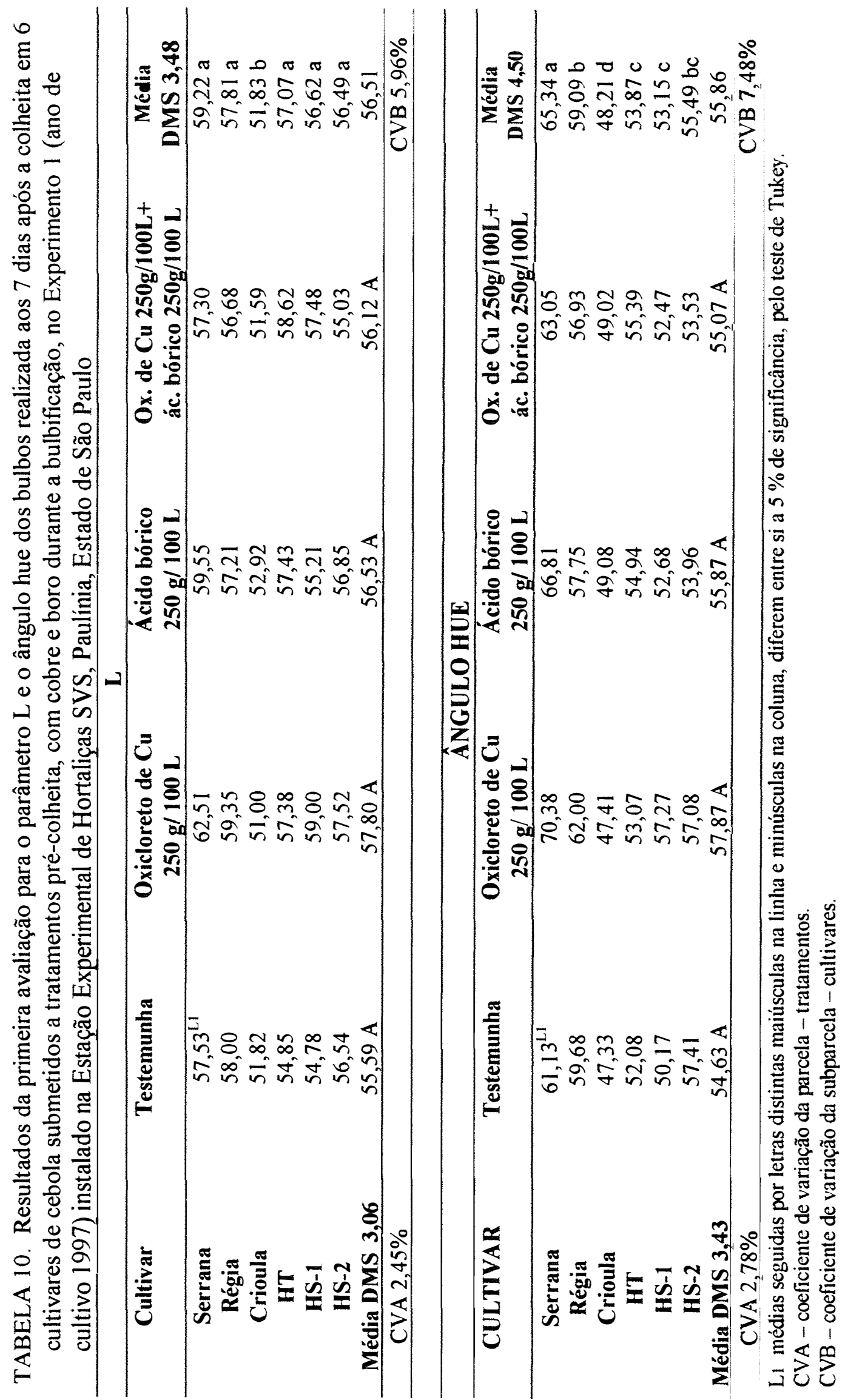




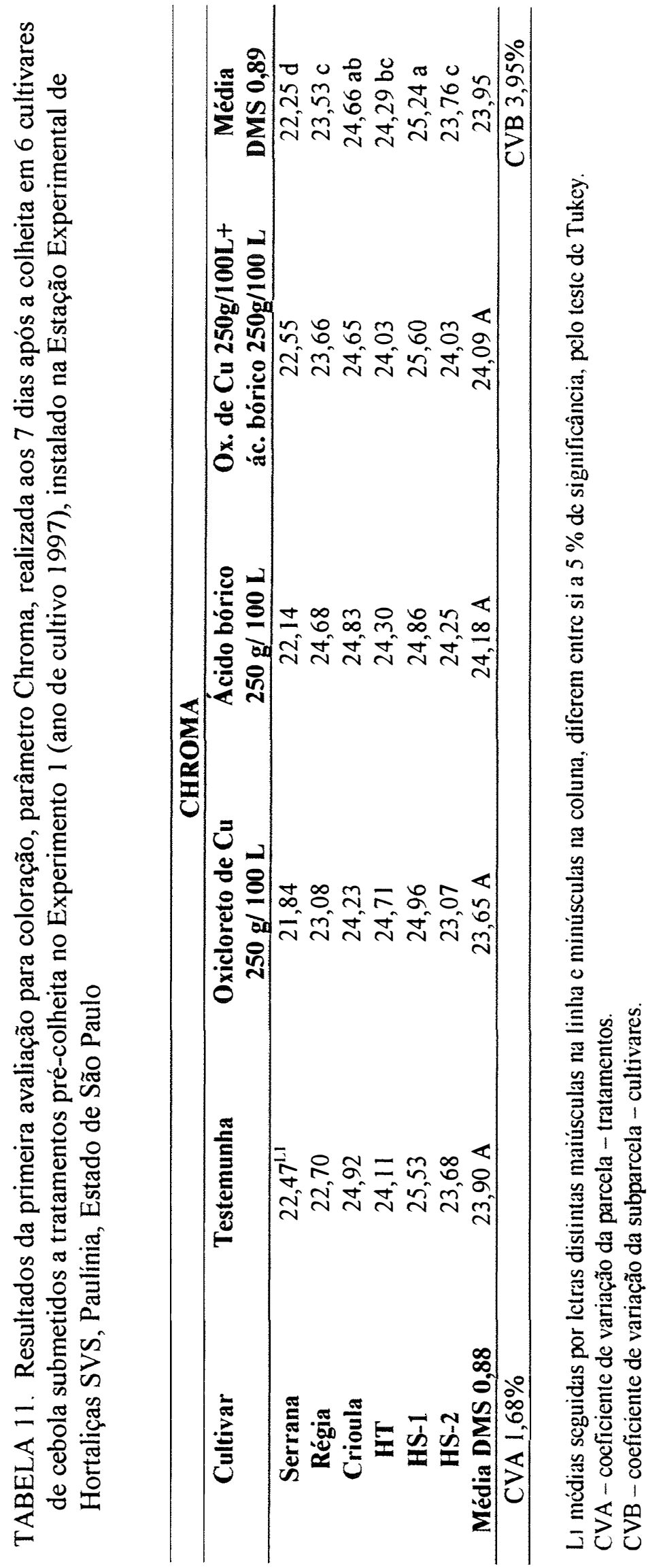


ambientais (Patil et al., 1995a). Doruchowski (1986a) descreve que do cruzamento de linhagens de coloração de casca distintas, o híbrido $F_{1}$ obtido possui casca de coloração intermediária, mais clara que o parental de cor mais escura. Observou-se neste experimento que os híbridos provenientes do cruzamento da variedade Crioula com linhagens macho-estéreis tipo baia-periforme possuem essa característica.

Pelas Tabelas 12 e 13 , nota-se que na segunda avaliação, 40 dias após a colheita, não houve diferença estatística entre os tratamentos em relação ao parâmetro L, ângulo hue e chroma. Novamente, 'Crioula' apresentou o menor valor de L, representando a cultivar de coloração mais escura, seguida pelo híbrido HS-1. As cultivares Régia e Serrana apresentaram menores valores de $\mathrm{L}$, portanto, de coloração mais clara. A variedade Crioula apresentou o menor valor do ângulo hue (Tabela 12), indicando uma coloração mais próxima ao vermelho. Os híbridos mostraram valores para o ângulo hue superiores à variedade Crioula, indicando valores mais distantes da cor avermelhada que a presente nessa variedade. O maior valor para o ângulo hue encontrado foi na variedade Serrana, sabidamente de coloração mais amarelada. Para o valor chroma (Tabela 13), não houve diferença entre as variedades e híbridos analisados, o que indica a não diferença para intensidade da coloração entre as cultivares dessa avaliação.

Observa-se pela Tabela 14, terceira avaliação, 60 dias após a colheita, que não houve diferença significativa entre os tratamentos utilizados para o valor L. Em relação às cultivares, novamente se repetiu o encontrado nas duas avaliações anteriores. A variedade Crioula apresentou menor valor para $\mathrm{L}$, representando uma coloração mais escura. 'Serrana' apresentou maior valor para L, representando coloração mais clara. 


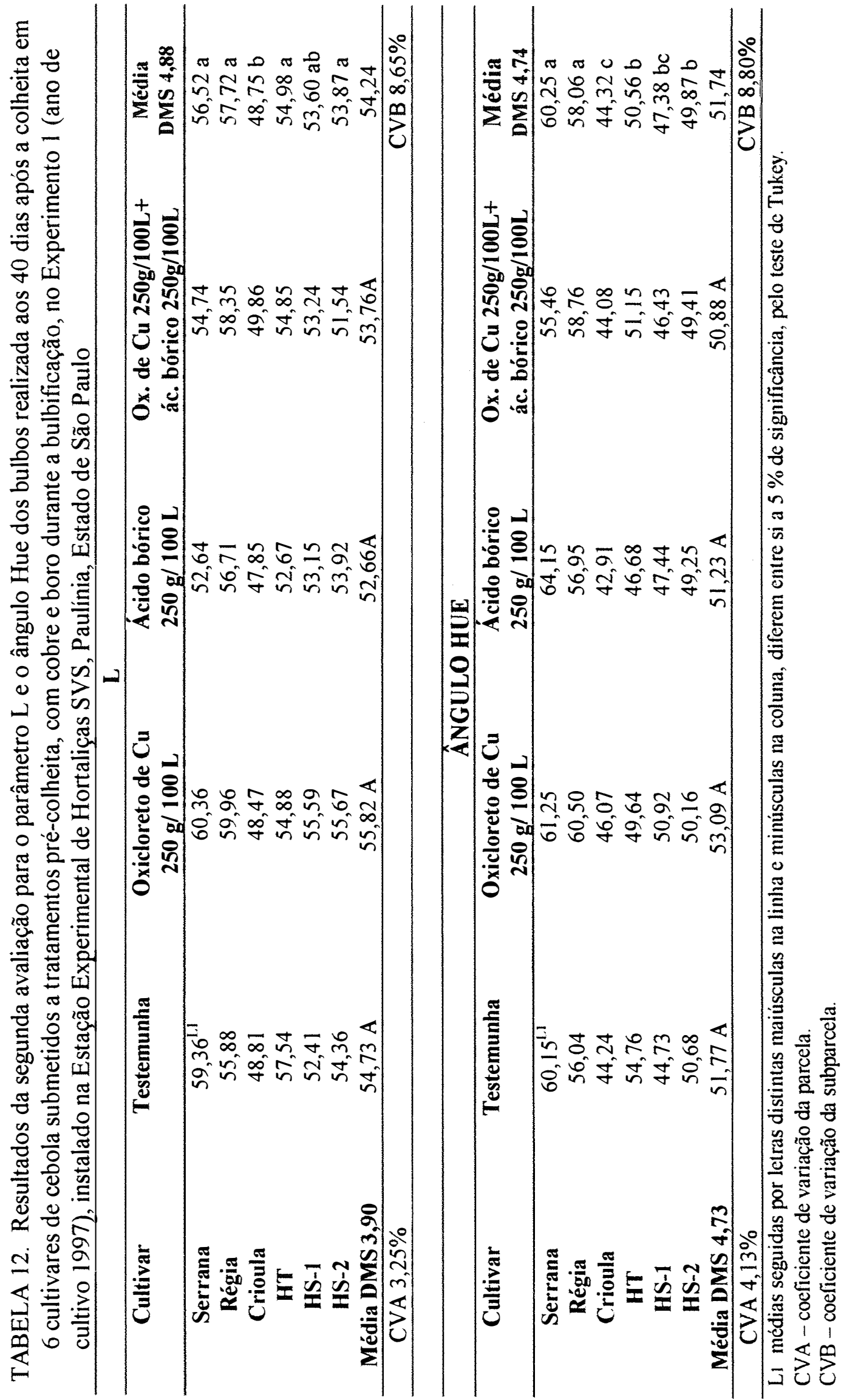




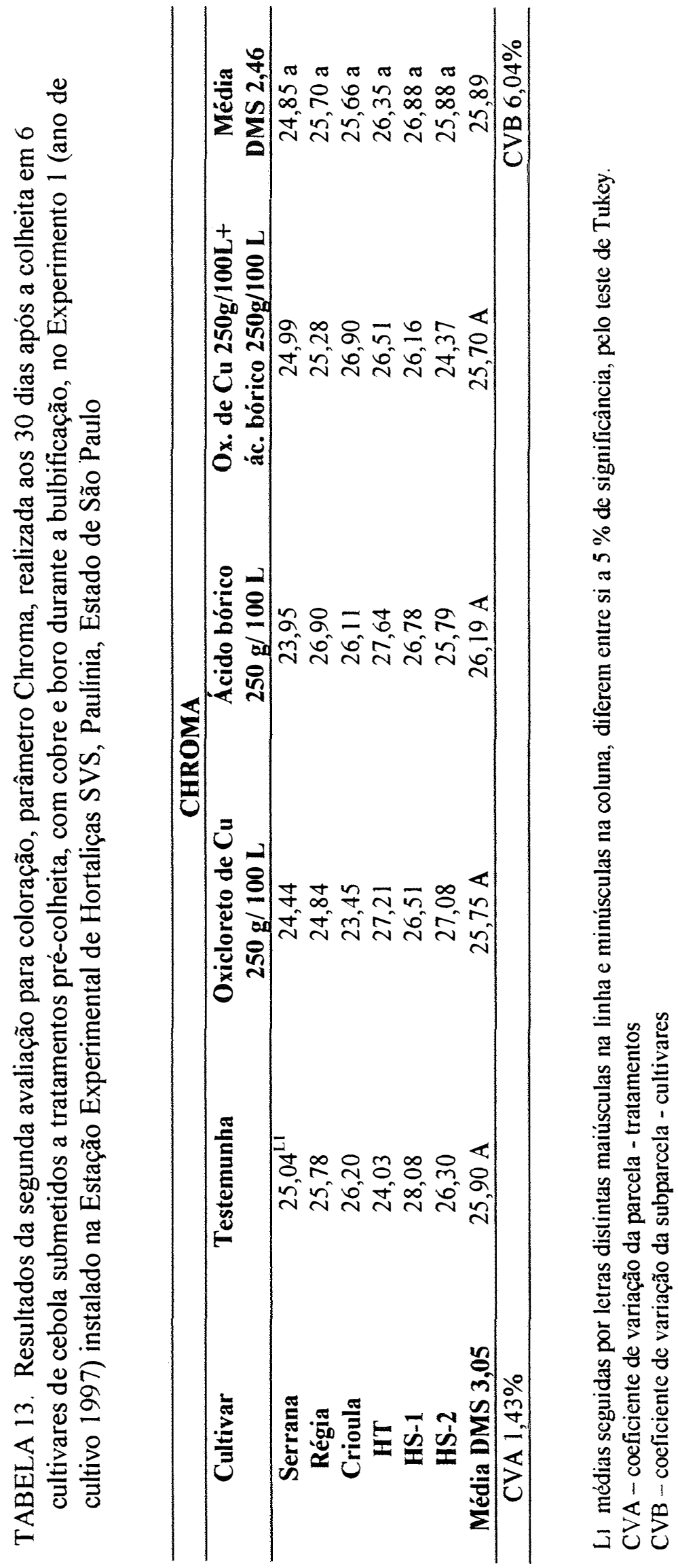




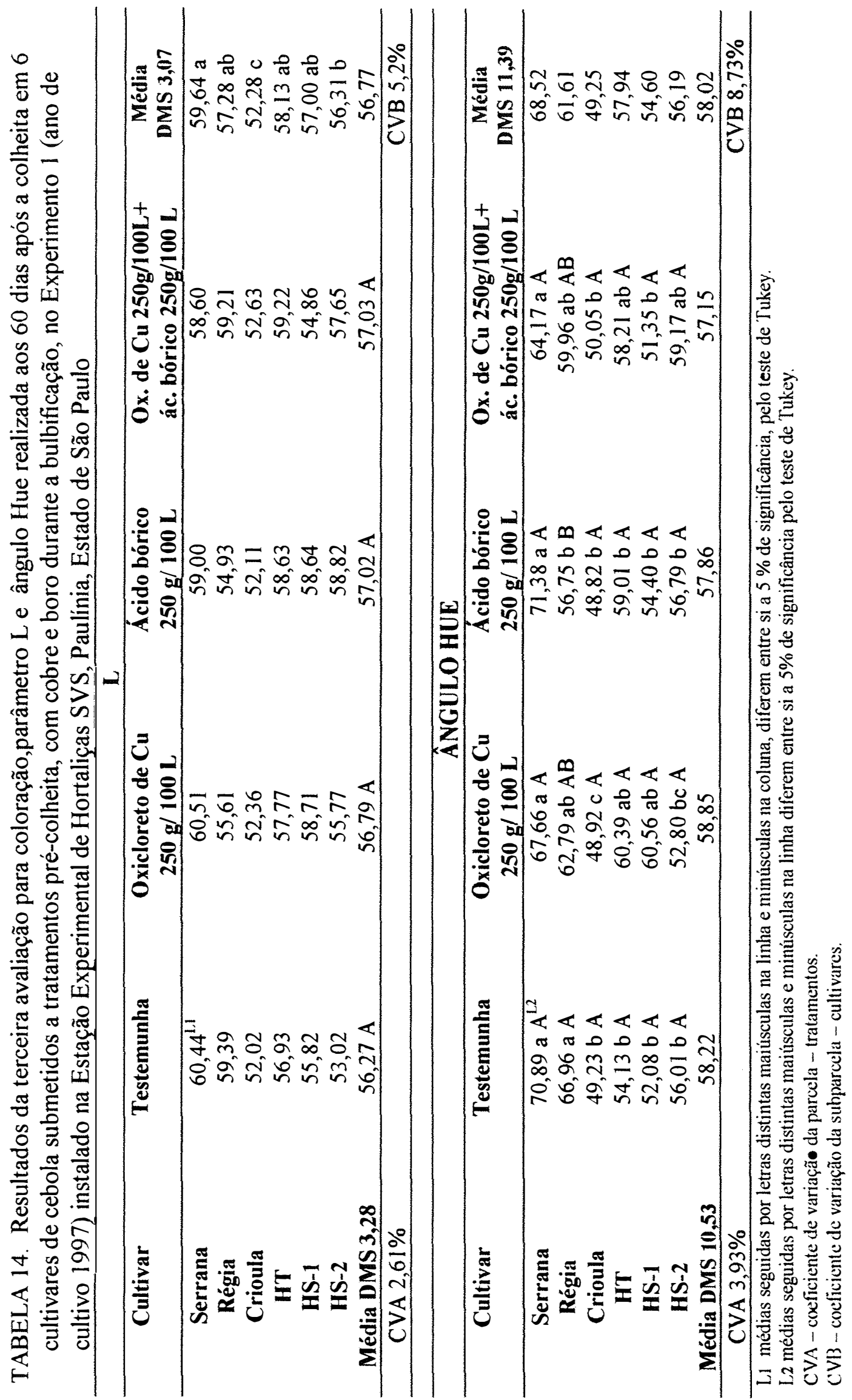


Os híbridos e a variedade Régia apresentaram valores intermediários para coloração de casca.

Para o parâmetro ângulo hue (Tabela 14) ocorreu uma interação entre o efeito dos tratamentos e o material genético. Observando as diferenças entre os tratamentos, nota-se que a variedade Régia apresentou menor valor para o ângulo hue, no tratamento com ácido bórico, $250 \mathrm{~g} / 100 \mathrm{~L}$ de água, significativamente diferente dos outros dois tratamentos: combinação oxicloreto de $\mathrm{Cu}$ e ácido bórico e oxicloreto de $\mathrm{Cu}, 250 \mathrm{~g} / 100$ L de água. Valores menores para o ângulo hue indicam coloração mais próxima do avermelhado. A testemunha apresentou maiores valores do ângulo hue, indicando coloração mais próxima do amarelo. Portanto, observa-se efeito dos tratamentos com micronutrientes na mudança de coloração da cebola nesta avaliação. Tanto Cu (Knott, 1933; Nelson et al., 1956; Murphy \& Walsh, 1973), quanto B (Calbo et al., 1986) influenciam a casca de cebola. A variedade Régia apresentou nas duas avaliações anteriores, para o parâmetro hue, valores indicativos para coloração mais próxima ao amarelo. Nesta avaliação, os valores apresentados estão mais próximos ao vermelho que a testemunha, apresentando efeito do tratamento. Além da influência dos tratamentos, o período de armazenamento (Patil et al., 1995b) e a temperatura (Cardoso et al., 1995) podem ter influenciado a alteração da cor.

Analisando separadamente cada tratamento, observa-se que no tratamento com oxicloreto de $\mathrm{Cu}, 250 \mathrm{~g} / 100 \mathrm{~L}$ de água, a variedade Crioula apresentou o menor valor do ângulo hue, estatisticamente diferente dos demais, indicando portanto, maior aproximação com a coloração vermelha. Observa-se comportamento semelhante no 
tratamento combinado, oxicloreto de cobre e ácido bórico. Na testemunha e no tratamento com ácido bórico, 'Crioula' e os híbridos demonstraram valores semelhantes, não diferindo estatisticamente. Observa-se para a 'Serrana' um maior valor para hue em todos os tratamentos, portanto, uma maior aproximação com a cor amarela.

Para o parâmetro chroma (Tabela 15), o tratamento com oxicloreto de $\mathrm{Cu}, 250$ g/100 L de água demonstrou maiores valores, significativamente diferentes dos demais tratamentos, independentemente da cultivar utilizada. Bender (1993) relata que a deficiência em $\mathrm{Cu}$ pode proporcionar bulbos de coloração mais clara. Maiores valores de chroma indicam uma maior intensidade luminosa. Os tratamentos ácido bórico, 250 g/100 L de água e associação oxicloreto de $\mathrm{Cu}$ e ácido bórico demonstraram valores intermediários, superiores à testemunha. Entre as cultivares utilizadas o maior valor de chroma foi apresentado no híbrido HS-1, seguido pela variedade Crioula e pelos híbridos HS-2 e HT. A variedade Régia apresentou um valor intermediário entre os híbridos (HS-2 e HT) e 'Serrana', que demonstrou o menor valor.

A maior resposta aos tratamentos nesta terceira avaliação para os parâmetros ângulo hue e chroma pode estar relacionado ao fato que durante o armazenamento ocorre o aumento da qüercitina, principal pigmento responsável pela coloração dos bulbos de cebola (Patil et al., 1995b), o que pode explicar valores mais significativos após 2 meses de armazenagem. 

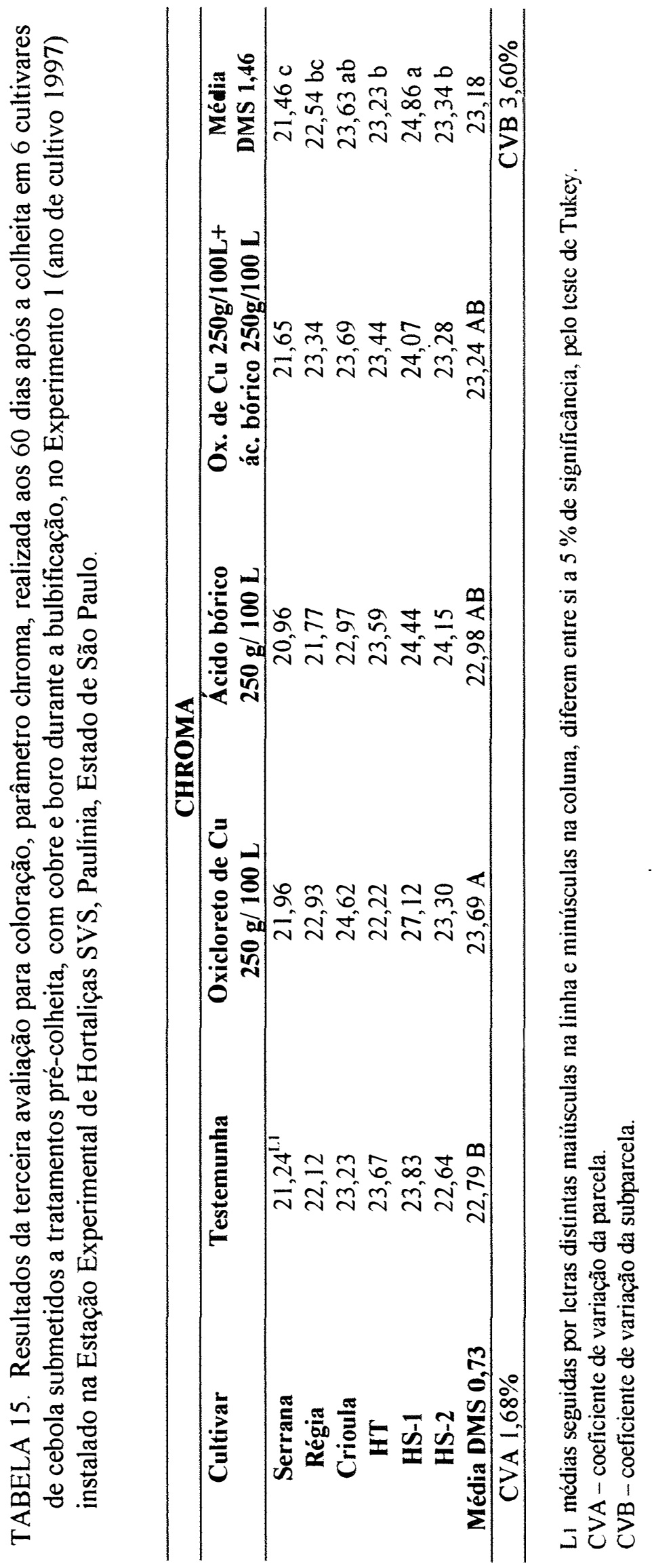


\subsection{Resultados Experimento 2 (ano de cultivo 1998)}

O experimento 2 , em relação ao experimento 1 , demonstrou uma variação nas cultivares quanto ao ponto de colheita. No Experimento 1, apesar de se trabalhar com cultivares de diferentes maturidades, a colheita foi realizada em uma mesma época. No experimento 2, a colheita foi efetuada em épocas diferentes. Uma das possíveis razões para isso pode estar relacionada às condições climáticas distintas em cada ano (tabelas 1 e 3). A média de temperatura nos dois anos foi muito semelhante. Quanto à pluviosidade houve uma grande diferença. No ano de 1997 , no período de abril a outubro, choveu $368,3 \mathrm{~mm}$, enquanto no ano de 1998 , no mesmo período, $416,3 \mathrm{~mm}$.

Em uma situação de menor disponibilidade de água, Experimento 1, ano de 1997, pode ter ocorrido a antecipação da bulbificação para os cultivares mais tardios.

Plantas de cebola quando expostas a condição de altas temperaturas e fotoperíodo longo ocorre indução à bulbificação (Currah \& Proctor, 1990; Mondal et al., 1986).

Em 1998, a distribuição das chuvas foi mais uniforme em cada mês e concentrada no fim do período. Essa diferença pode ter influenciado o processo de bulbificação. Em um ano mais chuvoso, a maior disponibilidade em água pode ocasionar maior crescimento vegetativo. Riekels (1977) relata atrasos na maturidade dos bulbos devido ao excesso na irrigação de 5-19 dias.

A colheita das 3 cultivares utilizadas no Experimento 2 foi realizada em duas épocas: 23 de outubro e 09 de novembro de 1998. Para efeito de cálculo para medições e avaliação dos resultados referentes ao Experimento 2, utilizou-se a última colheita como parâmetro, ou seja, 9 de novembro. 


\subsubsection{Perda de peso}

O cálculo para perda de peso foi idêntico ao Experimento 1. Foi realizada uma única avaliação para perda de peso. A primeira pesagem ocorreu 10 dias após a colheita da última cultivar a campo e a segunda, 30 dias após, efetuando então a avaliação para perda de peso. Utilizou-se a colheita da cultivar Crioula, em 9 de novembro de 1998, como parâmetro para as medições.

Não houve diferença significativa entre os tratamentos para perda de peso, expressa em porcentagem (Tabela 16). Uma das razões pode ser o maior período de tempo para realização das medições entre a primeira e segunda pesagem. Novamente o híbrido HS-1, não estatisticamente diferente da 'Crioula', apresentou menor perda de peso, quando comparado a variedade Serrana. Uma das razões pode ser a maior espessura da casca e provável uniformidade para estalo, características desse híbrido.

\subsubsection{Resistência da casca}

O teste para verificação da resistência da casca realizou-se 90 dias após a colheita e não foi encontrada diferença significativa entre os tratamentos (Tabela 17), talvez devido ao longo período anterior à avaliação. A variedade Crioula e o híbrido HS-1 apresentaram a maior resistência à penetração. 'Serrana' apresentou a menor resistência à penetração. Confirmando os resultados do ano anterior, Experimento 1, a variedade Crioula e o híbrido HS-1 demonstraram maior resistência de casca. 


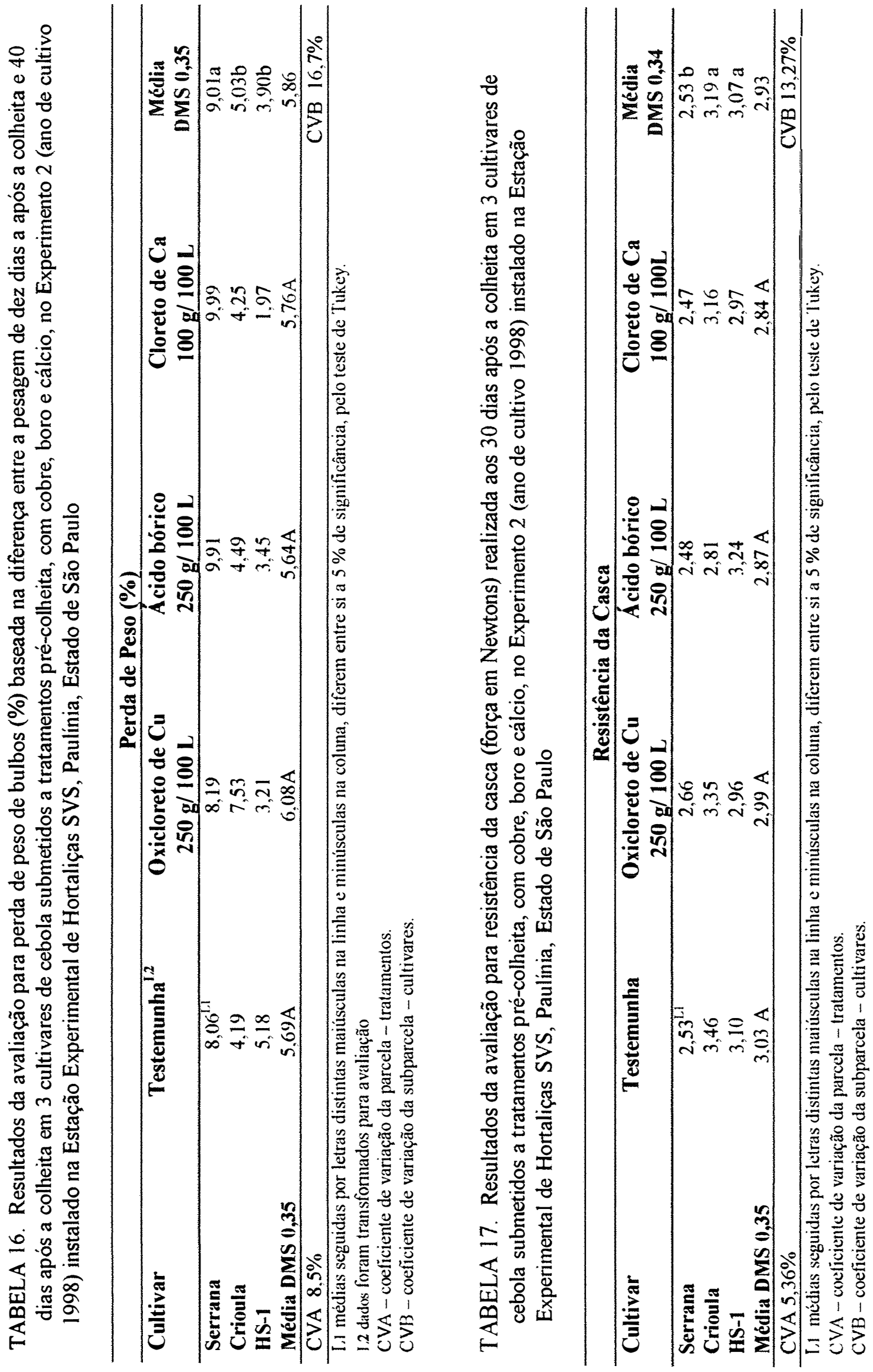




\subsubsection{Firmeza}

As medições para avaliação da firmeza dos bulbos foram feitas no texturômetro, através do teste de compressão (força em Newtons). Foram realizadas três avaliações aos 30, 75 e 90 dias após a colheita (Tabela 18).

Nas três avaliações, não foi detectada diferença entre os tratamentos para o parâmetro firmeza. Essa característica foi detectada visualmente, mas a análise estatística não revelou tal diferença. A variedade Crioula e o híbrido HS-1, novamente apresentaram maior resistência dos bulbos. Portanto, 'Serrana' apresentou menor resistência à penetração, ou seja, menor firmeza dos bulbos. A força média utilizada para penetração foi superior à utilizada do ano anterior.

\subsubsection{Cor}

Para avaliação da coloração dos bulbos também foram realizadas três avaliações, aos 30, 75 e 90 dias após a colheita.

Observa-se que na primeira avaliação para cor, Tabela 19, não houve diferença significativa entre os tratamentos para o parâmetro $\mathrm{L}$, ângulo hue e chroma. $\mathrm{O}$ tratamento com oxicloreto de $\mathrm{Cu}(250 \mathrm{~g} / 100 \mathrm{~L}$ de água), apresentou o menor valor de hue, mas não significativamente diferente dos outros tratamentos. Os tratamentos com oxicloreto de $\mathrm{Cu}$ e ácido bórico mostraram maiores valores em chroma, mas também não estatisticamente diferente dos demais.

A variedade Crioula e o híbrido HS-1 apresentaram o menor valor para $\mathrm{L}$ e ângulo hue e maior valor para chroma, representando portanto coloração mais próxima 


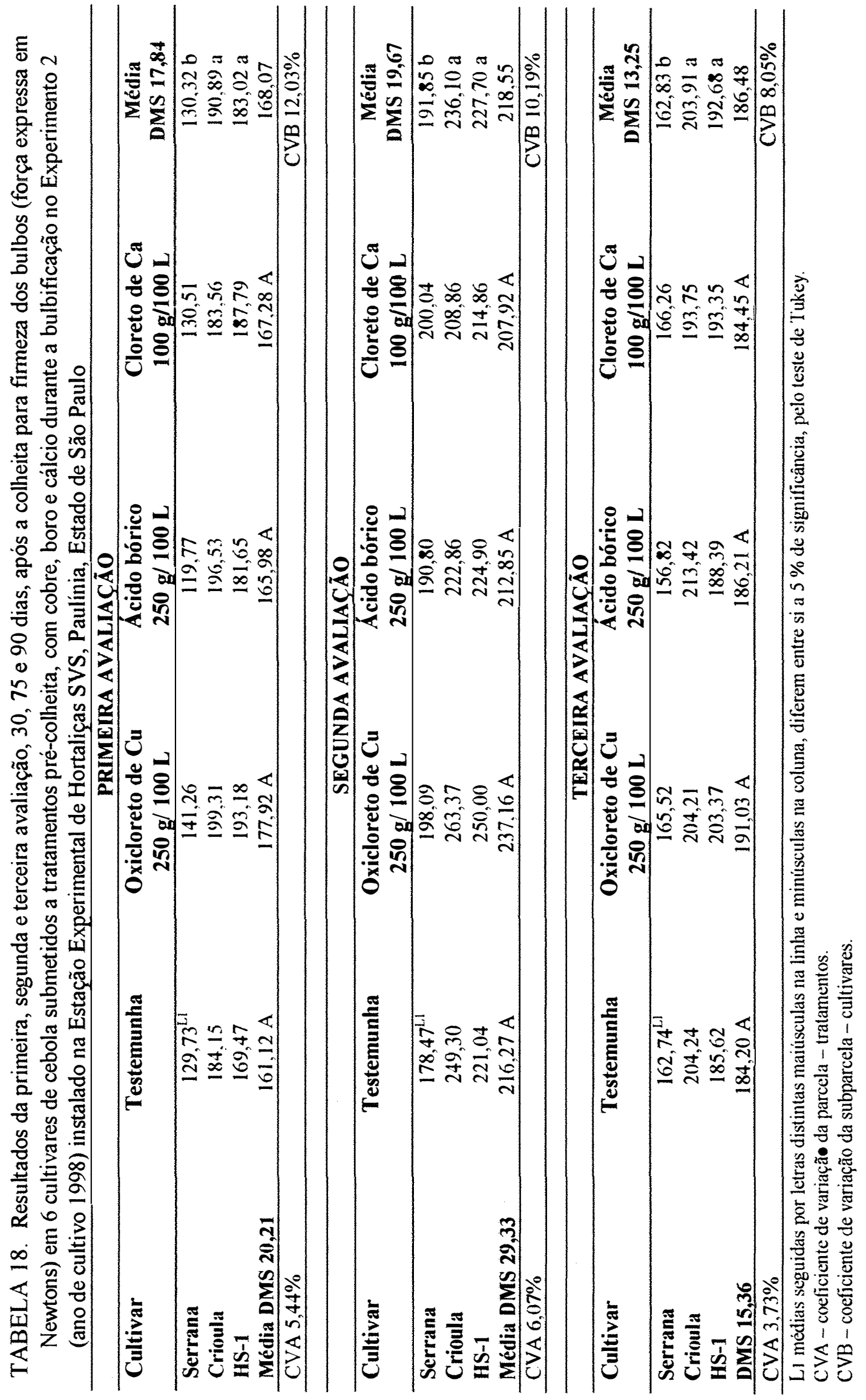




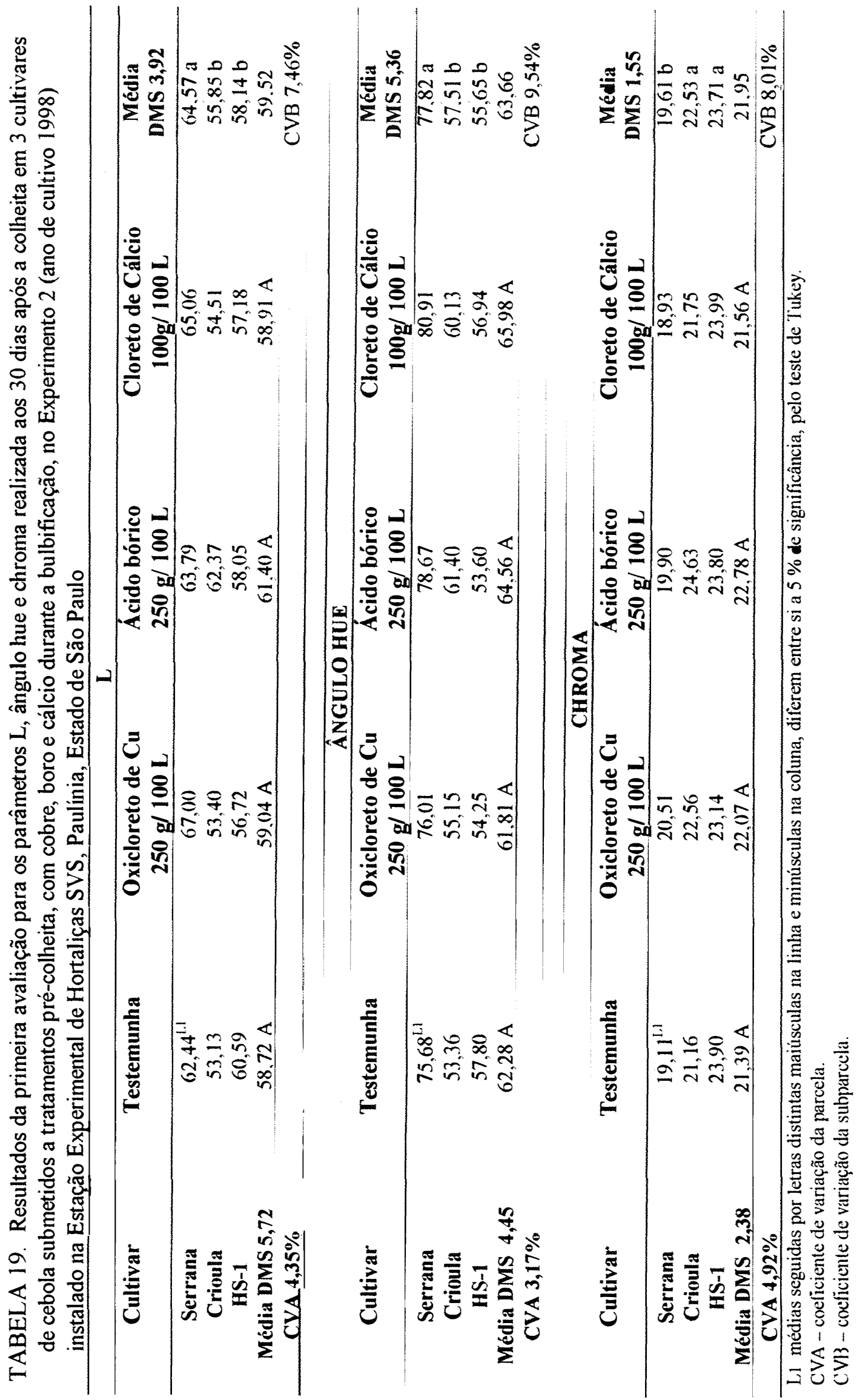


do vermelho. 'Serrana', apresentou o maior valor de L e ângulo hue e menor valor para chroma, demonstrando casca mais clara e mais amarelada e de menor intensidade luminosa.

Observa-se pela Tabela 20, segunda avaliação, 75 dias após a colheita, que não houve diferença estatistica entre os tratamentos para os parâmetros L, ângulo hue e chroma. O tratamento com oxicloreto de $\mathrm{Cu}, 250$ gramas/100 L de água, apresentou o menor valor de L, não estatisticamente diferente dos demais tratamentos. Os tratamentos com oxicloreto de cobre, $(250 \mathrm{~g} / 100 \mathrm{~L}$ de água) e com cloreto de $\mathrm{Ca},(100$ g/100 L de água) demonstraram os menores valores em hue, não estatisticamente diferentes da testemunha. O tratamento que apresentou maior valor de chroma foi o com cloreto de $\mathrm{Ca}(100 \mathrm{~g} / 100 \mathrm{~L}$ de água) não diferindo estatisticamente dos demais tratamentos.

A variedade Serrana mostrou o maior valor de $\mathrm{L}$ e ângulo hue, diferindo estatisticamente dos demais. Representando, portanto material de coloração de casca mais clara. A variedade Crioula e o hibrido HS-1, demonstraram maiores valores de L e ângulo hue. Não houve diferença estatistica entre as cultivares para chroma.

Pela Tabela 21, terceira avaliação, 90 dias após a colheita, observa-se que não houve diferença estatística entre os tratamentos utilizados para os parâmetros $L$, ângulo hue e chroma. O menor valor encontrado para o ângulo hue foi no tratamento com oxicloreto de $\mathrm{Cu}(250 \mathrm{~g} / 100 \mathrm{~L}$ de água), demonstrando maior escurecimento dos bulbos, mas não estatisticamente diferente dos demais.

A variedade Crioula e o híbrido HS-1 apresentaram menores valores para o parâmetro L e para o ângulo hue e maiores valores para chroma. Maior valor de chroma 
significa uma maior saturação, cores mais escuras. A variedade Serrana mostrou o maior valor do parâmetro L, maior ângulo hue e menor valor para chroma, diferindo estatisticamente dos demais, repetindo-se o resultado encontrado nas avaliações anteriores. 


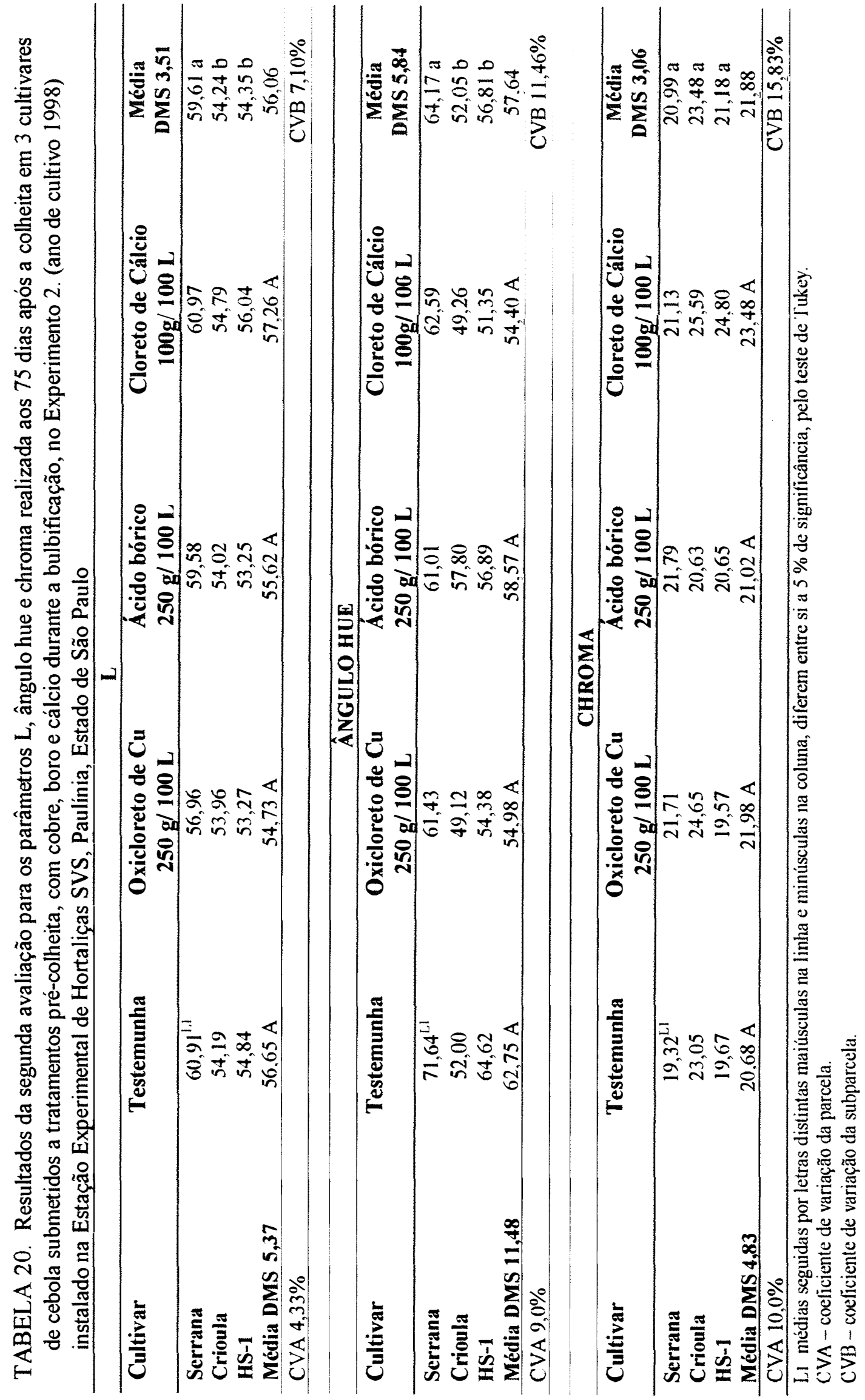




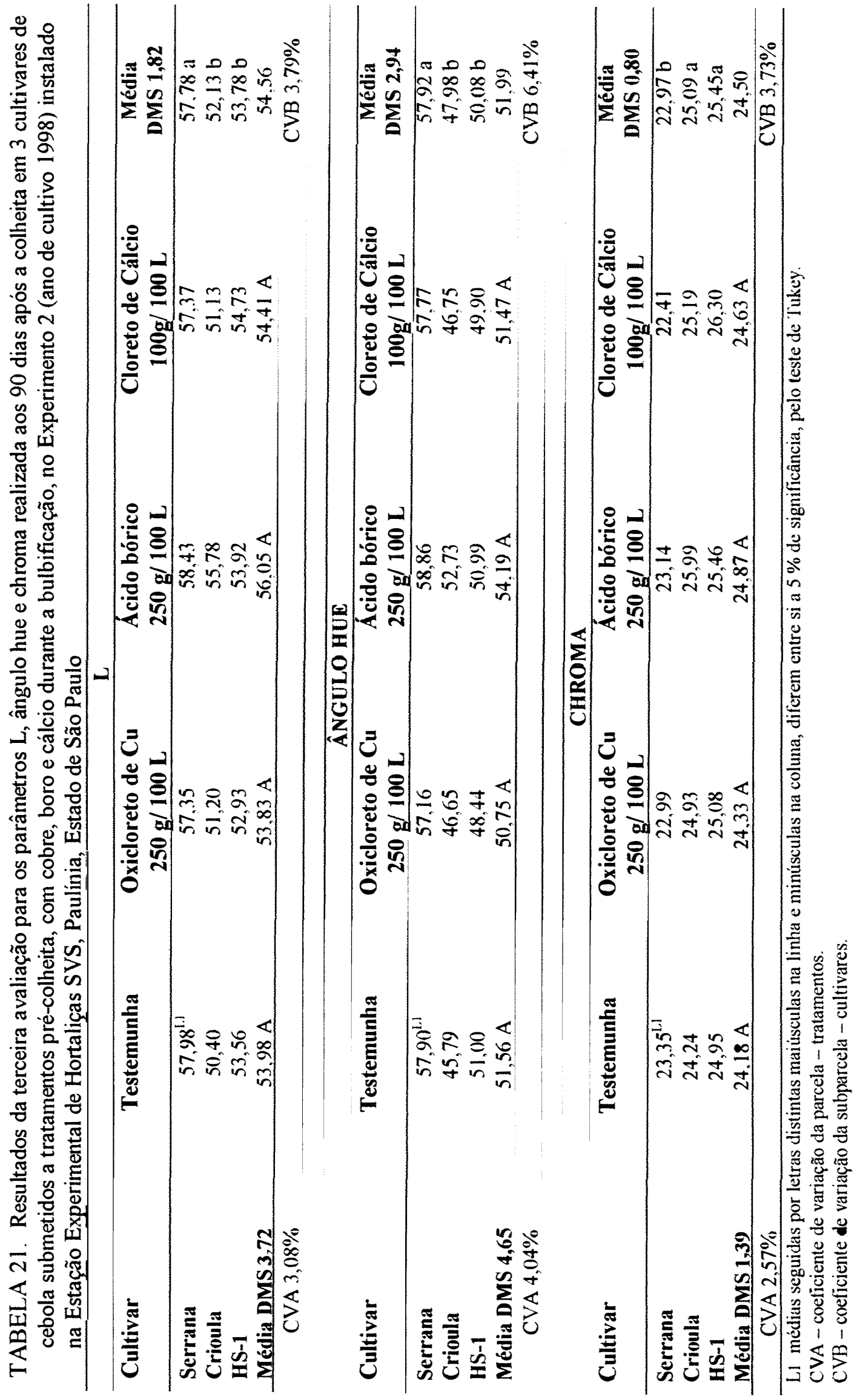




\section{CONCLUSÕES}

Os tratamentos pré-colheita, com os micronutrientes $\mathrm{Cu}$ e $\mathrm{B}$ aplicados durante a bulbificação da cebola, produziram uma melhoria na qualidade dos bulbos colhidos nos experimentos em 1997 e 1998. Bulbos tratados com micronutrientes apresentaram incremento na coloração e aumento da resistência da casca e menor perda de peso durante armazenamento. As seguintes conclusões foram observadas:

a) Aplicação em pré-colheita de oxicloreto de Cobre, $250 \mathrm{~g} / 100 \mathrm{~L}$, nas últimas semanas do ciclo, aumentou significativamente a resistência da casca do bulbo para todos os cultivares, em 1997.

b) O tratamento pré-colheita com oxicloreto de cobre, $250 \mathrm{~g} / 100 \mathrm{~L}$ reduziu a perda de peso dos bulbos para todas as cultivares, em 1997.

c) Os tratamentos pré-colheita com oxicloreto de cobre, $250 \mathrm{~g} / 100 \mathrm{~L}$ incrementaram a intensidade da cor e acentuaram a coloração avermelhada em todas as cultivares, em 1997. 
d) Os tratamentos pré-colheita com ácido bórico, $250 \mathrm{~g} / 100 \mathrm{~L}$ acentuaram a coloração avermelhada da variedade Régia, em 1997.

e) Cultivares de casca mais escura obtiveram maior resposta aos tratamentos précolheita para coloração do que cultivares de cor mais clara.

f) Para o parâmetro firmeza, nao foi observada nenhuma influência dos tratamentos précolheita, nas duas safras estudadas.

g) Observou-se uma menor perda em diâmetro durante armazenamento em bulbos tratados com $\mathrm{B}$ e $\mathrm{Cu}$, do que a testemunha.

h) Híbridos $F_{1}$ provenientes de cruzamento, cujo polinizador possuía casca de coloração escura e espessa, demonstraram valores intermediários para essas características.

i) No ano de 1998, visualmente, bulbos tratados com oxicloreto de cobre e cloreto de cálcio demonstraram incremento na coloração e firmeza. Infelizmente, essas diferenças não foram detectadas pela análise estatística. 


\section{REFERÊNCIAS BIBLIOGRÁFICAS}

ACOSTA, A.; GAVIOLA, J.C.; GALMARINI, C. Producción de semilla de cebolla. La Consulta: Asociación Cooperadora EEA La Consulta, 1993. 83p.

ALEXANDER, M.M.; SULEBELE, G. A. Pectic substance in onion and garlic skins. Journal of Science Food Agriculture, v. 24, p.611-615, 1973.

APELAND, J. Effects of scale quality in physiological processes in onion. Acta Horticulturae, v. 20, p.72-79, 1971.

BANKAR D.B.; DARA, S.S. Binding of calcium and magnesium by modified onion skins. Journal of Applied Polymer Science, v.27, p. 1727-1733, 1982.

BARTOLO, M. E.; SCHWARTZ, H. F.; SCHWEISSING, F. C. Yield and growth response of onion to simulated storm damage. HortScience, v.29, n. 12, p.1465$1467,1994$.

BENDER, D. A. Vegetable crops-Onion. In: Bennet, W.F (Ed.). Nutrient deficiencies \& toxicities in crop plants. St. Paul: The American Phytopathological Society, 1993. p.131-135.

BERNIER, G.; KINET, J. M; SACHS, R. M. The physiology of flowering. New York: CRC Press, 1981. 88p.

BILYK, A.; COOPER, P.L.; SAPERS, G.M. Varietal differences in distribution of quercitin and Kaempferol in onion (Allium cepa $\mathrm{L}$.) tissue. Journal of Agriculture Food Chemistry, v.32, p.274-276, 1984.

BLEASDALE, J.K.A.; TUCKER, W.G.; HOUGH, K. Bulk Storage of onions. Report of the National Vegetable Research Station for 1969, 1970. 79p.

BOEING, G. Cebola. Florianópolis: Instituto de Planejamento e Economia Agrícola de Santa Catarina, 1995. 85p. 
BREWSTER, J.L.; BUTLER, H.A. Effects of nitrogen supply on bulb development in onion( Allium cepa, L.). Journal of Experimental Botany, v.40, p.1155-1162, 1989.

BREWSTER, J.L.; LAWES, W.; WHITLOCK, A.J. The phenology of onion bulb development at different sites and its relevance to incomplete bulbing ('thicknecking'). Journal of Horticultural Science, v. 62, n. 3, p.371-378, 1987.

BRICE, J.; CURRAH, L.; MALINS, A.; BANCROFT, R. Onion storage in the tropics. A practical guide to methods of storage and their selection. Chatam, UK: Natural Resources Institute,. 1997. 116p.

CALBO, M.E.R.; MONNERAT, P.H.; SHIMOYA, C.. Caracterização de sintomas de deficiência de boro em cebola (Allium cepa $\mathrm{L}$.) em estádio de produção. Revista Ceres, v.33, n. 187, p.274-280, 1986.

CARDOSO, A.I.I.; DELLA VECCHIA, P.T.; FARIA, L.P. Herança de coloração de bulbos em cebola (Allium cepa $\mathrm{L}$.) com resistência a Colletotrichum gloeosporioides. Scientia Agricola, v.52, n.2, p.384-386, 1995.

CELARO, J. C.; GOMES, N. L. K. Conservação da cebola. Trigo e Soja, v.91, p.2730. 1987.

CHUNG, B. Irrigation and bulb onion quality. Acta Horticulturae, n.247, p.233-237, 1989.

CHURATA-MASCA, M.G.C.; CANALEZ, J.I. Nutrição e adubação da cebola. In: III SEMINÁRIO NACIONAL DA CEBOLA, Piedade, 1988. Anais. Piedade: SNC p.93-118.

CROZIER, A.; LEAN, M.E.J.; McDONALD, M.S.; BLACK, C. Quantitative analysis of the flavonoid content of commercial tomatoes, onions, lettuce, and celery. Journal of Agriculture Food Chemistry, v.45, p.590-595, 1997.

CURRAH, L.; PROCTOR, F.J. Onions in tropical regions. Bulletin $\mathbf{N}_{\mathrm{o} .35}$. Kent: Natural Resources Institute, 1990. 232 p.

DA GLÓRIA, B.A. Organografia Vegetal. Piracicaba: CALQ, 1995. 107p.

DELLA VECHIA, P.T. Produção de sementes de cebola. Piracicaba: CALQ, 1974. $100 \mathrm{p}$. 
DORNENBURG, H.; KNORR, D. Generation of colors and flavors in plant cell and tissue cultures. Critical Reviews in Plant Sciences, v.15, n.2, p.141-168, 1996.

DORUCHOWSKI, R.W. Variability and hereditability of some onion (Allium cepa L.) characteristics of parental forms, $F_{1}$ hybrids and $F_{2}$ generation. Acta Agrobotanica, v.39, p.293-324, 1986a.

DORUCHOWSKI, R.W. Inheritance of different undertones of onion (Allium cepa L.) dry skin color and the relationship between color and adherence. Acta Agrobotanica, v.39, p.341-345, 1986b.

ELLERBROCK, L.A. Copper requirements for onions grown on organic soils in New York. Acta Horticulturae, n.433, p.567-571, 1997.

EL-SHAFIE, M.W.; DAVIS, G.N. Inheritance of bulb color in the onion (Allium cepa L.). Hilgardia, v. 38, n.17, p.607-622, 1967.

FENN, L.B.; TAYLOR, R.M.; BURKS, C.M. Influence of plant age on calcium stimulated ammonium absorption by radish and onion. Journal of Plant Nutrition, v. 16, n. 7, p. 1161-1177, 1993

FENWICK, G.R.; HANLEY, A.B. The Genus Allium. Part 2. CRC-Critical-Reviewsin-Food-Science-and-Nutrition, v. 22, n.4, p.273-377, 1985.

FERNANDES, P.D. Micronutrientes em hortaliças. In: REUNIÃO ANUAL DA SOCIEDADE DE OLERICULTURA DO BRASIL, 11. Piracicaba, 1971. Resumo. Piracicaba: SOB. 39p.

FERRI, M.G.; MENEZES, N.L.; MONTEIRO, W.R. Glossário ilustrado de botânica. São Paulo: Nobel, 1981. 120p.

FNP Consultoria \& Comércio. Anuário Estatístico da Agricultura Brasileira-1999. São Paulo: FNP, 1999. 440p.

FONTES, R.R. Solos, calagem e adubação química para a cultura da cebola. Informe Agropecuário, v.62, p.21-26, 1980.

FOSSEN, T.; ANDERSEN, A.T.; OVSTEDAL, D.O.; PEDERSEN, A.T.; RAKNES, A. Characteristic anthocyanin pattern from onions and other Allium spp. Journal of Food Science, v.61, n.4, p.703-706, 1996.

FOSSEN, T.; PEDERSEN, A.T.; ANDERSEN, O.M. Flavonoids from red onion (Allium cepa). Phytochemistry, v.47, n.2, p.281-285, 1998. 
FRANCOIS, L.E. Yield and quality responses of garlic and onion to excess boron. HortScience, v.26, n. 5, p.547-549, 1991.

FUSTOS, Z.S. The role of the dry scale in the dormancy of onions (Allium cepa $\mathrm{L}$.). Acta Horticulturae, n.433, p.445-446, 1997.

HAAG, P.H.; MINAMI, K.; DECHEN, A.R. Micronutrientes em Hortaliças. Campinas: Fundação Cargill, 1982. 26p.

HARDENBURG, R.E; WATADA, A.E.; WANG, C.Y. The Commercial storage of fruits, vegetables, and florist and nursery stocks. Washington, DC: U.S. Department of Agriculture, 1986. 136p.

HOLLMAN, P.C.H.; TRIJP, J.M.P.; BUYSMAN, M.N.C.P. Fluorescence detection of flavonols in HPLC by postcolumn chelation with Aluminum. Analytical Chemistry, v. 68, p.3511-3515, 1996.

IWANA, S.; HAMASHIMA, N. Ecological studies of vegetables at the region of different altitudes. 5. Ecological behaviours of onion under varying daylength and temperature conditions. Journal of the Japanese Society for Horticultural Science, v.22, 95-99, 1953.

JONES, H.A. \& MANN, L.K. Onions and their allies. London: Leonard Hill, 1963. $286 \mathrm{p}$.

KATO, T. Physiological studies on bulb formation and dormancy in the onion plant. VI. The relationships between the metabolism of gibberellin and nucleic acid and bulb formation. J. Hortic. Assoc. Japan, v.34, p.305-310, 1965.

KNOTT, J.E. The effect of certain mineral elements on the color and thickness of onion scales. Ithaca: Cornell Agricultural Experiment Station, 1933. 14p.

Bulletin 552.

LANCASTER, J.E.; GANDAR, P.W. Towards, a descriptive framework for the growth of onions. Proceedings of the Agronomy Society of New Zealand. v. 16. p. 87-92, 1986.

LANCASTER, J.E.; LISTER, C.E.; READY, P.F.; TRIGGS, C.M. Influence of pigment composition on skin color in a wide range of fruit and vegetables. Journal of American Society of Horticultural Science. v.122, n.4, p.594-598, 1997 
LEIGHTON, T; GINTHER, C.; FLUSS, L.; HARTER, W.K.; CANSADO, J.; NOTARIO, V. Molecular characterization of quercitin and quercitin glycosides in Allium vegetables. American Chemical Society-Symposium series, n.507, p.220238, 1992.

MALAVOLTA, E.; HAAG, H.P.; MELLO, F.R.P.; BRASIL SOBRINHO, M.O.L. Nutrição mineral e adubação das plantas cultivadas. São Paulo: Livraria Pioneira, 1974. 752p.

MARSCHNER, H. Mineral Nutrition of Higher Plants. Londres, Academic Press, 1986. Cap. 9, p.269-340: Functions of mineral nutrients: Micronutrients.

MATOS, A.A. Cura e armazenamento de cebola com utilização de ventilação forçada - Armazenagem, modelo EMPASC. Florianópolis: EMPASC, 1987. 21 p. EMPASC-Comunicado Técnico n. 113.

MAW, B.W.; HUNG, Y.C.; TOLLNER, E.W.; SMITTLE, D.A.; MULLINIX, B.G. Detecting impact damage of sweet onions using muriatic acid and X-rays. Applied Engineering in Agriculture, v. 11, n.6, p.823-826, 1995.

McGUIRE, R.G. Reporting of objective color measurements. HortScience, v. 27, n.2, p.1254-1255, 1992.

MONDAL, M.F.; BREWSTER, J.L.; MORRIS, G.E.L.; BUTLER, H.A. Bulb development in onion (Allium cepa L.). I. Effects of plant density and sowing date in field conditions. Annals of Botany, v.58, n.2, p.187-195, 1986.

MURPHY, L.S.; WALSH, L.M. Correction of micronutrient deficiencies with fertilizers. In: DINAUER, R.C. (Ed.). Madison: Soil Science Society of America, 1973. cap.15, p.347-388: Micronutrients in Agriculture.

NELSON, L.G.; BERGER, K.C.; ANDRIES, H.J. Copper requirements and deficiency symptoms of a number of field and vegetable crops. Soil Science American Proceedings, v.20, p.69-72, 1956.

PALTA, J.P. Role of calcium in plant responses to stresses: linking basic research to the solution of practical problems. HortScience, v.31, n.1, p.51-57, 1996.

PARK, Y-K.; LEE, C.Y. Identification of isorhamnetin 4'-glucoside in onions. Journal of Agriculture Food Chemistry, v.44, p.34-36, 1996. 
PATIL, J.A.; DEOKAR, A.B.; MASLEKAR, S.R. Inheritance of bulb colour in onion. Research Journal of Mahatama-Phule-Agricultural-University, v.2, n. 1, p.92-93, 1971.

PATIL, B.S.; PIKE, L.M. Distribution of quercitim content in different rings of various coloured onion (Allium cepa) cultivars. Journal of Horticultural Science. v.70, n.4, p.643-650, 1995.

PATIL, B.S.; PIKE, L.M.; HAMIL TON, B.K. Changes in quercitin concentration in onion (Allium cepa L.) owing to location, growth stage and soil type. New Phytologist, v.130, p.349-355, 1995a.

PATIL, B.S.; PIKE, L.M.; YOO, K.S. Variation in the quercitin content in different colored onions (Allium cepa L.). Journal American Society of Horticultural Science, v. 120, n.6, p.909-913, 1995b.

PIKE, L.M. Onion Breeding. In: BASSET, M. (Ed.) Breeding Vegetable Crops. Westport: AVI Publishing, 1986. p. 357-394.

PRICE, K.R.; BACON, J.R.; RHODES, M.J.C. Effect of storage and domestic processing on the content and composition of flavonol glucosides in onion (Allium cepa L.). Journal of Agriculture and Food Chemistry, v.45, p.938-942, 1997.

PURVIS, E.R. \& CAROLUS, R.L. Hunger Signs in Crops. In: SPRAGUE, H.B. (Ed.). Nutrient deficiencies in vegetable crops. New York: David McKay, 1951, cap. 7, p.245-286.

RABINOWITCH, H.D.; BREWSTER, J.L. Onions and Allied Crops. Boca Raton: CRC Press, 1990. $273 \mathrm{p}$

RAIJ, B. van.; CANTARELLA, H.; QUAGGIO, J.A.; FURLANI, A.M.C. Recomendações de adubação e calagem para o Estado de São Paulo. 2.ed. Campinas: Instituto Agronômico \& Fundação IAC, 1996. 285p.

RIEKELS, J.W. Nitrogen-water relationships of onions grown on organic soil. Journal of American Society of Horticultural Science, v.102, p. 139, 1977.

SAFARIKOVA, R. Evaluation of compactness and cracking of onions skins. SbornikUvtiz. v. 13, n.1, p.64-71, 1986.

SALLAM, L.A.R.; EL-REFAI, A.H.; EDREES, M.; ABDEL-FATTAH, A.F. Studies on the outer pigmented skins of onions. Qualitas-Plantarum, v.24, n.1-2, p.159$162,1974$. 
SARGENT, S.A., ZOELLNER, J.J., STOFFELA, P.J., MAYNARD, D.N.. Harvest maturity affects storage quality of fresh, short-day onions. Proceedings Florida State Horticultural Society, v. 104, p.64-68, 1991.

SHEWFELT, R.L.; THAI, C.N.; DAVIS, J.W.. Prediction of changes in color of tomatoes during ripening at different constant temperatures. Journal of Food Science, v.53, n.5, p.1433-1437, 1988.

SOBEIH, W.Y. The photoperiodic regulation of bulbing in onions (Allium cepa L.). IV. The translocation of ${ }^{14} \mathrm{C}$-assimilate during bulbing in response to light and hormonal factors. Journal of Horticultural Science, v.38, n. 1, p.109-1 18, 1988.

SOBEIH, W. Y.; WRIGHT, C. J. Effect of ethylene and silver ions on bulbing in onions (Allium cepa L.) under different light regimes. Scientia Horticulturae, v.31, p.45$52,1986$.

STEER, B.T. The bulbing response to day-lenght and temperature of some Australasian cultivars of onion (Allium cepa L.). Australian Journal Agriculture Research, v.31, p. $511,1980$.

TANAKA, M., YOSHIKAWA, H. \& KOMOCHI, S.. Studies on the storage of autumn harvested onion bulbs. IV. Peeling and physical characteristics of onion skins during storage. Research Bulletin of the Hokkaido National Agricultural Experiment Station, n.144, p.31-50, 1995.

TERABUN, M. Studies on bulb formation in onion plants, IV. Swelling of the basal sheath induced by removal of the apical bud under short day conditions. J. Hortic. Assoc. Japan, v.39, p. 245, 1970.

TOLEDO, J.; SHERMAN, M; HUBER, J. Some effects of cultivar, bulb size and preharvest treatments on storage characteristics of North Florida onions.

Proceedings Florida State Horticultural Society, v.97, p. 106-108, 1984.

TUCKER, W.G.; DREW, R.L. K. Post-harvest studies on autumm-drilled bulb onions. The effect of harvest date, conditioning treatments and field drying on skin quality and on storage performance. Journal of Horticultural Science, v.57, n.3, p.339-348, 1982.

WERNER, R.A.; SEBEN, J.C. Cura e armazenamento da cebola. Florianópolis: EMPASC, 1983. 71p. 
WRIGHT, C.J., \& SOBEIH, W.J. The photoperiodic regulation of bulbing in onions (Allim cepa L.). I. Effects of irradiance. Journal of Horticultural Science, v.61, n.3, p.331-335, 1986.

WRIGHT, P. \& GRANT, D. Perfect onions. Commercial Grower, v.51, n.2, p.17-18, 1996. 